\title{
NPC1-regulated dynamic of clathrin-coated pits is essential for viral entry
}

\author{
Guoli $\mathrm{Li}^{1,2 \dagger}$, Bingqian Su ${ }^{1,2 \dagger}$, Pengfei $\mathrm{Fu}^{1,2}$, Yilin Bai ${ }^{4}$, Guangxu Ding ${ }^{1,2}$, Dahua $\mathrm{Li}^{1,2}$, \\ Jiang Wang ${ }^{1,2,3}$, Guoyu Yang ${ }^{1,2,3^{*}} \&$ Beibei Chu ${ }^{1,2,3^{*}}$ \\ ${ }^{1}$ College of Veterinary Medicine, Henan Agricultural University, Zhengzhou 450046, China; \\ ${ }^{2}$ Key Laboratory of Animal Biochemistry and Nutrition, Ministry of Agriculture and Rural Affairs of the People's Republic of China, \\ Zhengzhou 450046, China; \\ ${ }^{3}$ International Joint Research Center of National Animal Immunology, Henan Agricultural University, Zhengzhou 450046, China; \\ ${ }^{4}$ College of Veterinary Medicine, Northwest A\&F University, Yangling 712100, China
}

Received January 4, 2021; accepted April 12, 2021; published online May 27, 2021

\begin{abstract}
Viruses utilize cellular lipids and manipulate host lipid metabolism to ensure their replication and spread. Therefore, the identification of lipids and metabolic pathways that are suitable targets for antiviral development is crucial. Using a library of compounds targeting host lipid metabolic factors and testing them for their ability to block pseudorabies virus (PRV) and vesicular stomatitis virus (VSV) infection, we found that U18666A, a specific inhibitor of Niemann-Pick C1 (NPC1), is highly potent in suppressing the entry of diverse viruses including pseudotyped severe acute respiratory syndrome coronavirus 2 (SARS-CoV-2). NPC1 deficiency markedly attenuates viral growth by decreasing cholesterol abundance in the plasma membrane, thereby inhibiting the dynamics of clathrin-coated pits (CCPs), which are indispensable for clathrin-mediated endocytosis. Significantly, exogenous cholesterol can complement the dynamics of CCPs, leading to efficient viral entry and infectivity. Administration of U18666A improves the survival and pathology of PRV- and influenza A virus-infected mice. Thus, our studies demonstrate a unique mechanism by which NPC1 inhibition achieves broad antiviral activity, indicating a potential new therapeutic strategy against SARS-CoV-2, as well as other emerging viruses.
\end{abstract}

broad-spectrum antiviral, NPC inhibition, CCP dynamics, viral entry

Citation: Li, G., Su, B., Fu, P., Bai, Y., Ding, G., Li, D., Wang, J., Yang, G., and Chu, B. (2022). NPC1-regulated dynamic of clathrin-coated pits is essential for viral entry. Sci China Life Sci 65, 341-361. https://doi.org/10.1007/s11427-021-1929-y

\section{INTRODUCTION}

Viral infection represents one of the leading causes of human and animal diseases worldwide despite significant improvements in medical care and public health (Lozano et al., 2012). It is impossible to control these infections in a timely and effective manner at their onset due to the long time lag required to develop vaccines and specific antiviral drugs.

†Contributed equally to this work

*Corresponding authors (Guoyu Yang, email: haubiochem@163.com; Beibei Chu, email: chubeibei@henau.edu.cn)
However, during epidemics, infected individuals need to be treated urgently. At present, a novel pathogenic virus designated severe acute respiratory syndrome coronavirus 2 (SARS-CoV-2) is causing a pandemic (Coronaviridae Study Group of the International Committee on Taxonomy of Viruses, 2020) that is significantly impacting on human health and the global economy (Zhou et al., 2020). Therefore, broadspectrum antivirals could help improve patient's health outcomes and accelerate the control of such epidemics.

Broad-spectrum antivirals that act on multiple viruses can be developed by different strategies (Wisskirchen et al., 2014). Historically, antiviral drug discovery mainly focused 
on virus-encoded targets because of the high specificity and fewer side effects. However, the disadvantage of using viral targets is that viruses are diverse, both in structure and in replication strategies. Moreover, the elevated mutation rate of viruses can also lead to the emergence of drug resistance (Menendez-Arias et al., 2014; Smith et al., 2019). An alternative strategy to circumvent these limitations is targeting the cellular metabolism or host cell factors exploited by different viruses. Thus, drugs that inhibit a specific cellular target could work for several viruses.

As viruses are intracellular obligate pathogens, they cannot replicate without the machinery and metabolic resources of a host cell. Lipids have long been recognized as structural elements of cellular and viral membranes, but recent studies have revealed their involvement in viral proliferation, including entry, uncoating, genome replication, assembly, and progeny virion release (Barrows et al., 2018; Li et al., 2019; Lorizate and Kräusslich, 2011; Moriishi and Matsuura, 2012; Stapleford and Miller, 2010). Taking advantage of cellular lipids to facilitate viral multiplication is a strategy shared by non-enveloped and enveloped viruses, as well as both DNA and RNA viruses (Altan-Bonnet, 2017). It has been proposed that lipids can function as viral entry receptors. For instance, gangliosides serve as receptors for members of the polyomavirus family (Tsai and Qian, 2010), and negatively charged phospholipids, such as phosphatidylserine, can be used by vesicular stomatitis virus (VSV) (Carneiro et al., 2006). In particular, sphingolipid- and cholesterol-enriched lipid raft microdomains in the plasma membrane (PM) (Lingwood and Simons, 2010) have been related to the entry of a variety of viruses, including SARS-CoV-2 (Wang et al., 2008), herpes simplex virus (HSV) (Bender et al., 2003), and murine leukemia virus (Li et al., 2002). Once viruses enter the cytoplasm of the host cell, they induce the rearrangement of lipid metabolism to facilitate viral multiplication (Heaton and Randall, 2011; Targett-Adams et al., 2010). Many RNA viruses remodel the endomembrane to form specialized replication sites, and phosphatidylinositol 4 (PI4) kinase beta is recruited to generate PI4-phosphate (PI4P), creating a PI4Penriched microenvironment to facilitate viral replication ( $\mathrm{Li}$ et al., 2019; Miller and Krijnse-Locker, 2008). The characterization and modulation of cellular lipid metabolic pathways commonly used by large classes of viruses may aid the development of novel broad-spectrum antivirals.

In this study, we screened a library of compounds targeting proteins involved in various pathways of lipid metabolism with antiviral activity against pseudorabies virus (PRV) (DNA virus) and VSV (RNA virus). We identified U18666A, which demonstrates potent and broad-spectrum antiviral activity. Liscum and Faust demonstrated that U18666A inhibits the exit of cholesterol from lysosomes, thereby creating the equivalent of NPC1 deficiency (Liscum and Faust, 1989). NPC1 is a lysosomal membrane protein that exports cholesterol derived from the receptor-mediated uptake of low-density lipoprotein (LDL) (Cruz et al., 2000). U18666A treatment or NPC1 deficiency markedly decreased viral entry via interference with the dynamics of clathrin-coated pits (CCPs). We found that U18666A suppresses the function of NPC1, thereby preventing the transport of cholesterol from the lysosome to the PM, which inhibits CCP dynamics, and thus attenuates viral entry via clathrin-mediated endocytosis (CME). Importantly, exogenous cholesterol can restore the requirement of CCP dynamics during viral entry. In vivo, U18666A treatment improved survival and reduced lung damage in PRV- and influenza A virus-infected mice, suggesting that U18666A has potential as a novel broad-spectrum antiviral for controlling emerging/recurring infections by viruses that enter cells via CME.

\section{RESULTS}

\section{U18666A exerts broad-spectrum antiviral activity}

To investigate the potential druggable lipid metabolic pathways that may lead to the inhibition of a panel of DNA viruses and RNA viruses, we screened a library of 19 compounds that targeting proteins/enzymes with putative functions in the synthesis of fatty acids, cholesterol, cholesterol esters, and cholesterol transport (Figure S1A and B in Supporting Information). We performed the screen in PK-15 cells infected with DNA virus (PRV co-expressing a GFP reporter, PRV-GFP) or RNA virus (VSV co-expressing a GFP reporter, VSV-GFP) for our preliminary study. PRV and VSV infected cells were treated with the indicated compounds, and GFP-positive cells were quantified $36 \mathrm{~h}$ after infection (Figure 1A and B; Figures S2 and S3 in Supporting Information). Flow cytometry analyses indicated that modulation of host lipid metabolism could significantly change the outcome of virus infection with no toxicity (Figure S4A in Supporting Information). We found that the sterol regulatory element-binding protein (SREBP) site 1 protease (S1P) inhibitor PF429242, which inhibits proteolytic processing of SREBP, thereby decreasing the transcriptional activation of lipid synthetic genes (Monnerie et al., 2017), protected PK-15 cells against PRV and VSV infection. We also found that FASN inhibitor (FAS-IN-1) and stearoylCoA desaturase (SCD) inhibitors (A939572, MK-8245, and PluriSIn 1) suppressed viral proliferation at non-toxic concentrations, while RNA virus (VSV) was more sensitive to these inhibitors than the DNA virus (PRV). FASN and SCD are known to regulate de novo fatty acid synthesis. FASN has been demonstrated to be critical for the replication of many viruses (Zhang et al., 2019). SCD was also reported to define hepatitis virus $\mathrm{C}(\mathrm{HCV})$ replication efficiency (Nio et al., 2016). Notably, U18666A, a specific inhibitor of NPC1 that blocks the movement of cholesterol out of lysosomes, dis- 

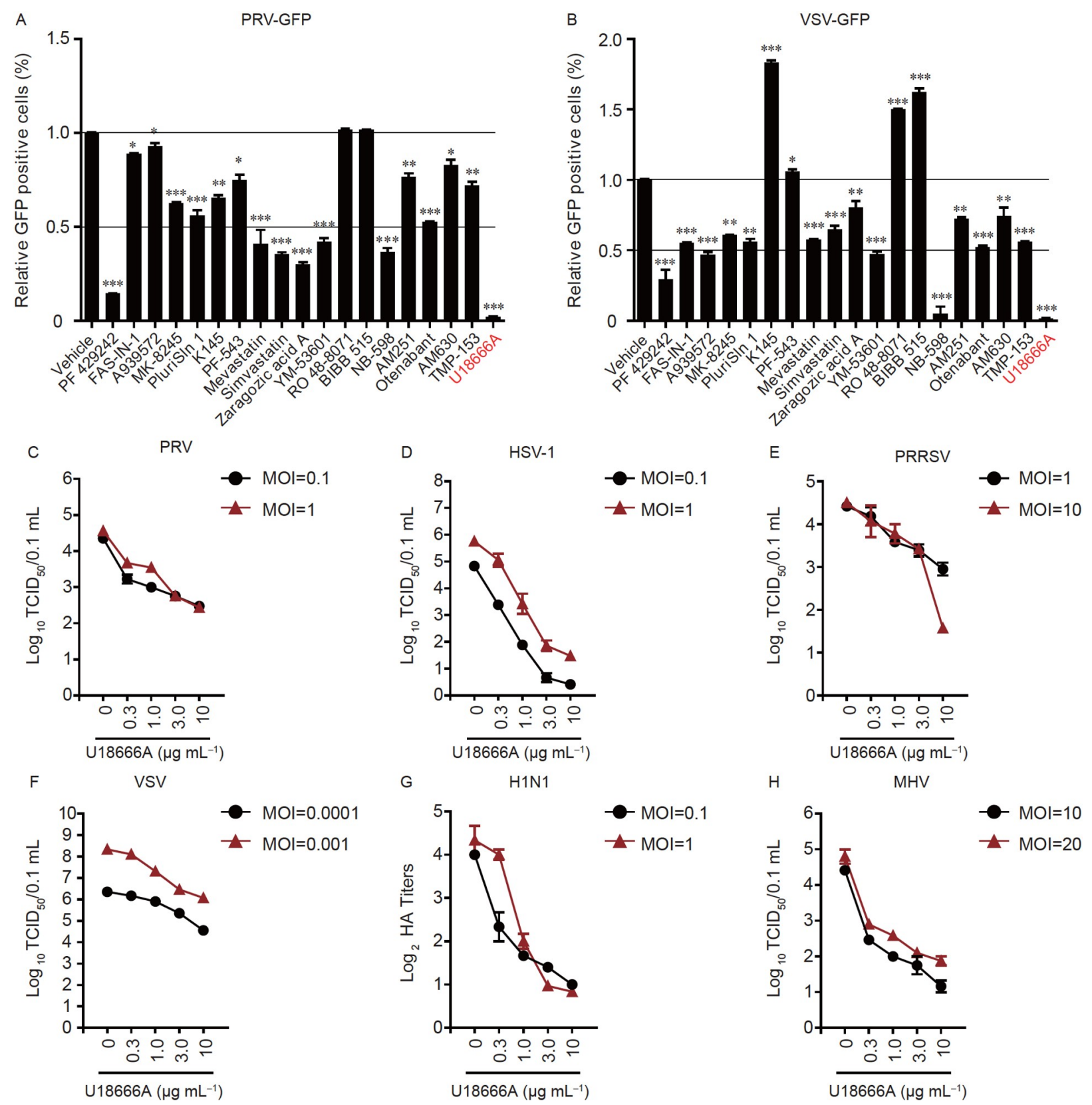

Figure 1 U18666A exerts broad-spectrum antiviral activity. A and B, PK-15 cells were treated with the indicated compounds for $4 \mathrm{~h}$ followed by PRV-GFP $(\mathrm{A}, \mathrm{MOI}=0.01)$ or VSV-GFP $(\mathrm{B}, \mathrm{MOI}=0.00001)$ infection and simultaneous treatment with the indicated compounds for $36 \mathrm{~h}$ to detect GFP-positive cells by flow cytometry. C, PK-15 cells were treated with U18666A $\left(0-10 \mu \mathrm{g} \mathrm{mL}^{-1}\right)$ for $4 \mathrm{~h}$ followed by infection with PRV HN1201 (MOI=0.1 and 1$)$ for $24 \mathrm{~h}$ to detect the viral titer by a TCID 50 assay. D, A549 cells were treated with U18666A $\left(0-10 \mu \mathrm{g} \mathrm{mL}^{-1}\right)$ for $4 \mathrm{~h}$ followed by infection with HSV1-F (MOI=0.1 and 1) for $24 \mathrm{~h}$ to detect the viral titer by a $\mathrm{TCID}_{50}$ assay. E, MARC-145 cells were treated with U18666A $\left(0-10 \mu \mathrm{g} \mathrm{mL} \mathrm{L}^{-1}\right)$ for $4 \mathrm{~h}$ followed by infection with PRRSV BJ-4 (MOI=1 and 10) for $48 \mathrm{~h}$ to detect the viral titer by a TCID ${ }_{50}$ assay. F, PK-15 cells were treated with U18666A $\left(0-10 \mu \mathrm{g} \mathrm{mL} \mathrm{L}^{-1}\right)$ for $4 \mathrm{~h}$ followed by infection with VSV-GFP (MOI=0.0001 and 0.001 ) for $24 \mathrm{~h}$ to detect the viral titer by a $\mathrm{TCID}_{50}$ assay. G, MDCK cells were treated with U18666A $\left(0-10 \mu \mathrm{g} \mathrm{mL}^{-1}\right)$ for $4 \mathrm{~h}$ followed by infection with H1N1-PR8 (MOI=0.1 and 1$)$ for $36 \mathrm{~h}$ to detect the viral titer by a HA assay. H, L929 cells were treated with $\mathrm{U} 18666 \mathrm{~A}\left(0-10 \mu \mathrm{g} \mathrm{mL}^{-1}\right)$ for $4 \mathrm{~h}$ followed by infection with MHV A59 (MOI=10 and 20) for $36 \mathrm{~h}$ to detect the viral titer by a TCID ${ }_{50}$ assay. ${ }^{*}, P<0.05$; $* *, P<0.01 ; * * *, P<0.001$; one-way ANOVA.

played the most significant inhibitory effect against DNA and RNA viruses (Figure 1A and B). These findings highlighted the intimate connections between lipid metabolism and viral infection, further strengthening our hypothesis of modulating cellular lipid metabolism for antiviral development.
Next, we investigated the antiviral effect of U18666A against other viruses in vitro, including DNA viruses (PRV HN1201 and HSV1-F) and RNA viruses (porcine reproductive and respiratory syndrome virus (PRRSV BJ-4), VSV-GFP, influenza A H1N1, and mouse hepatitis virus (MHV) A59 strain) by viral titer assays. Consistently, the 
administration of U18666A significantly inhibited the proliferation of all evaluated viruses in a dose-dependent manner (Figure 1C-H). Collectively, these results suggest that U18666A inhibits a broad spectrum of viral pathogens.

\section{U18666A inhibits viral infections in an NPC1-dependent manner}

U18666A is a compound that directly binds to the sterolsensing domain of NPC1, which blocks the export of cholesterol from lysosomes ( $\mathrm{Lu}$ et al., 2015). Since U18666A protects cells against multiple viral infections, NPC1 deficiency might suppress viral replication. To evaluate the role of NPC1 in viral infections, we generated NPC1-ablated PK15 cell lines using the clustered regularly interspaced short palindromic repeats/CRISPR-associated protein 9 (CRISPR/ Cas9) system (targeting exon 2 of $\mathrm{Npcl}$ as shown by the sequencing data in Figure S4B in Supporting Information), and the genetic ablation efficiency is shown in Figure 2A. Marked reductions in viral yield were also obtained in $\mathrm{NPC}^{\mathrm{KO}}$ cells, and the viral infections could be fully restored by the expression of wild-type NPC1 (Figure 2B and C). To assess the specificity of U18666A, we included the NPC1 ${ }^{\text {WT }}$ control as well as $\mathrm{NPC1}^{\mathrm{KO}}$ cells to detect PRV and VSV replication. Importantly, U18666A treatment significantly reduced the infection of control cells but failed to cause an additive inhibition of viral replication in $\mathrm{NPCl}^{\mathrm{KO}}$ cells (Figure 2B and C), suggesting that U18666A mainly blocks the function of NPC1 to diminish PRV and VSV infection.

Moreover, we used an NPC1-null cell line (Chinese hamster ovary (CHO) CT43) to determine whether NPC1 is required for viral infection. Concordantly, in contrast to CHO-K1 cells with wild-type NPC1, CT43 cells demonstrated significant inhibition of VSV replication (Figure 2D). Our experiments also confirmed that $\mathrm{CHO}$ cells are inefficient target cells for PRV (data not shown) (Nixdorf et al., 1999). In addition, posaconazole and itraconazole are two other potent NPC1 inhibitors (Trinh et al., 2017). Our results demonstrated that both posaconazole and itraconazole efficaciously inhibited proliferation of the evaluated viruses in a dose-dependent manner (Figure 2E and F). Overall, these findings indicate that U18666A exerts its antiviral effect through an NPC1-dependent pathway.

\section{NPC1 inhibition has no apparent role in viral attach- ment}

To determine whether U18666A acts on the virus, we first pretreated live PRV with U18666A, washed, re-purified viral particles from the excess compound, and tested virus infectivity. Figure 3A shows that treatment did not affect viral infectivity, indicating that U18666A does not inactivate
A
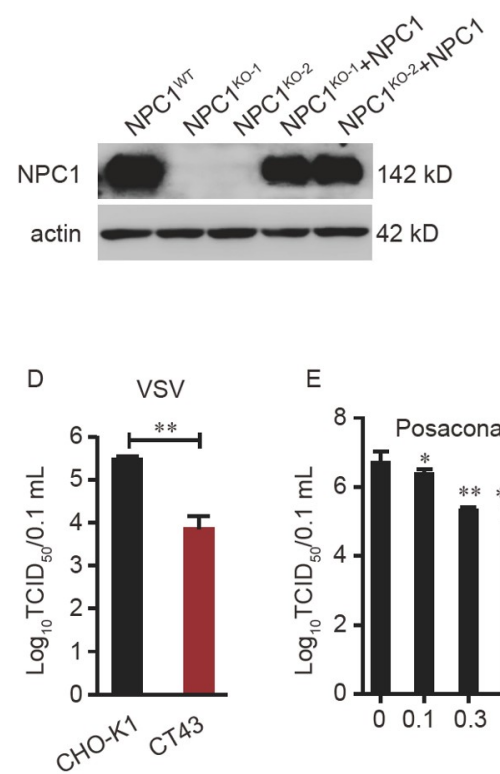

B

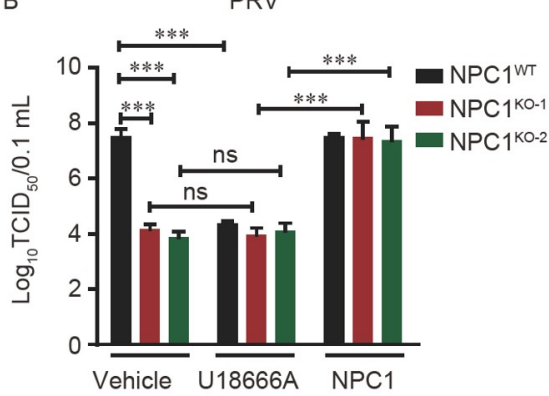

$\mathrm{C}$

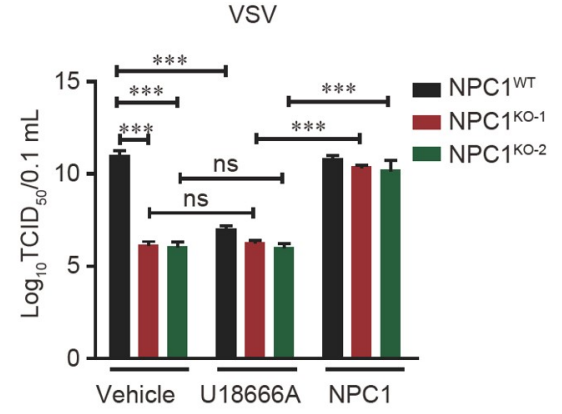

Figure 2 The antiviral activity of U18666A is dependent on NPC1. A, The expression of NPC1 protein was checked in the CRISPR/Cas9-Control $\left(\mathrm{NPC} 1^{\mathrm{WT}}\right), \mathrm{CRISPR} / \mathrm{Cas} 9-\mathrm{Npc1}$ knockout $\left(\mathrm{NPC1}^{\mathrm{KO}}\right)$, and $\mathrm{NPC1}{ }^{\mathrm{KO}}$ re-expressing $\mathrm{NPC1}\left(\mathrm{NPC} 1^{\mathrm{KO}}+\mathrm{NPC} 1\right) \mathrm{PK}-15$ cells by an immunoblot assay. B and C, Cells were treated with vehicle or U18666A $\left(10 \mu \mathrm{g} \mathrm{mL}^{-1}\right)$ followed by infection with PRV HN1201 (E, MOI=1) or VSV-GFP (F, MOI=0.001) for 24 h. The viral titers in $\mathrm{NPC}^{\mathrm{KO}}$ cells re-expressing NPC1 were also tested by a TCID ${ }_{50}$ assay. D, CHO-K1 and CT43 cells were infected with VSV-GFP (MOI=0.0001) for $24 \mathrm{~h}$ and the viral titer was assessed by a TCID ${ }_{50}$ assay. E, PK-15 cells were treated with posaconazole $\left(0-3 \mu \mathrm{mol} \mathrm{L}^{-1}\right)$ or itraconazole $\left(0-3 \mu \mathrm{mol} \mathrm{L}^{-1}\right)$ for $4 \mathrm{~h}$ followed by infection with PRV HN1201 (MOI=1) for $24 \mathrm{~h}$ to determine the viral titer by a TCID 50 assay. F, PK-15 cells were treated with posaconazole $\left(0-3 \mu \mathrm{mol} \mathrm{L}^{-1}\right)$ or itraconazole $\left(0-3 \mu \mathrm{mol} \mathrm{L}^{-1}\right)$ for $4 \mathrm{~h}$ followed by infection with VSV-GFP (MOI=0.001) for $24 \mathrm{~h}$ to determine the viral titer by a TCID 50 assay. *, $P<0.05$; **, $P<0.01$; ***, $P<0.001$; ns, not significant; one-way ANOVA. 
virions. To investigate the effects of U18666A on cells, we performed a time-of-addition assay wherein the drug was added to PK-15 cells $4 \mathrm{~h}$ before PRV infection (pre-treatment) or after infection (post-infection) and cells were incubated to detect the viral titer. The inhibitory effect of $\mathrm{U} 18666 \mathrm{~A}$ in pretreated cells was more evident than in posttreated cells (Figure $3 \mathrm{~B}$ and $\mathrm{C}$ ), suggesting that this drug modulates host cells before viral infection. Next, we investigated the stage of the viral life cycle inhibited by U18666A. PK-15 cells were treated with vehicle control or $\mathrm{U} 18666 \mathrm{~A}$ for $4 \mathrm{~h}$, and then PRV was incubated with cells at $4^{\circ} \mathrm{C}$ for $2 \mathrm{~h}$ to allow for viral attachment to cells but not entry. After washing with cold PBS, quantification of PRV genomic DNA showed no statistical difference between the vehicle and U18666A groups (Figure 3D). We also labeled the PRV genome with 5-ethynyl-2'-deoxyuridine (EdU) and examined viral attachment with Apollo staining. In cells treated with vehicle or U18666A, there was no significant reduction in the PRV genome (Figure 3E and F). Concurrently, treatment with U18666A did not reduce the attachment of VSV (Figure 3G) or SARS-CoV-2 spike-bearing pseudoviruses (Figure $3 \mathrm{H}$ and I). To further validate these results, we tested whether PRV and VSV attachment is affected in NPC1-deficient cells. As expected, there was no reduction in the amount of PRV (Figure 3J) or VSV (Figure $3 \mathrm{~K}$ ) attached to $\mathrm{NPC}^{\mathrm{KO}}$ versus NPC1 ${ }^{\mathrm{WT}}$ cells, as measured by immunoblotting and qRT-PCR. Taken together, the antiviral activity of U18666A does not affect viral attachment.

\section{NPC1 inhibition blocks viral entry}

Unlike the effect observed on viral attachment, when cells were infected with EdU-labeled PRV at $37^{\circ} \mathrm{C}$ for $15 \mathrm{~min}$, our data revealed a significant drop in the intracellular PRV genome fluorescence intensity compared with the vehicle control (Figure 4A and B), suggesting that U18666A blocks PRV internalization into the host cell. A biotinylation-trypsinization endocytosis assay also demonstrated that U18666A prevented PRV internalization in a dose-dependent manner (Figure 4C). Furthermore, the entry of PRV or VSV genome into cells treated with U18666A was lower than in cells treated with the vehicle (Figure 4D and E). Consistent with this, NPC $1^{\mathrm{KO}}$ cells showed reduced PRV or VSV genome copy numbers (Figure 4F and G).

Further support of these findings was provided by electron micrographs showing that PRV virions mostly fused with the PM to enter cells in the control group. Conversely, viruses in cells pre-treated with U18666A were mostly attached to the cell surface (Figure 4H and I). Viral titer assays of PRV demonstrated that U18666A did not block viral replication (Figure 4J) or release (Figure 4K). Therefore, NPC1 inhibition protects cells from virus infection by blocking viral entry. Specifically, it does not affect the viral replication and release processes.

\section{NPC1-dependent virus entry relies on CME}

The entry of enveloped viruses into cells occurs via two primary pathways: either through direct membrane fusion with the PM at the cell surface or by taking advantage of host cell's endocytic machinery (Grove and Marsh, 2011). We noticed that NPC1 inhibition did not affect viral attachment/ fusion to cells (Figures 3 and 4H). Therefore, we focused on identifying the specific endocytic pathway involved in NPC1-dependent virus entry. The endocytic pathways exploited by viruses to enter target cells include macropinocytosis, CME, and the caveolae-dependent pathway (Mercer and Helenius, 2009). To probe the relevant endocytic pathway, we used a panel of endocytosis chemical inhibitors. The cytotoxic effects of each inhibitor were tested, and concentrations that minimally impacted cell viability were used. Each chemical inhibitor was added $4 \mathrm{~h}$ before virus infection and was present during infection. Blebbistatin (Jiang et al., 2010) and EIPA (Mercer and Helenius, 2009) are widely used inhibitors of macropinocytosis. When added before infection, neither Blebbistatin nor EIPA had a statistically significant effect on PRV infectivity (Figure 5A).

Similarly, pretreatment with Filipin III and Nystatin, caveolae-mediated endocytosis inhibitors, did not suppress viral replication (Figure 5B). Among the inhibitors tested, we noted that treatment with CME inhibitors chlorpromazine (CPZ) (Shin et al., 2013) and phenylarsine oxide (PAO) (Bourke et al., 2003) could significantly reduce PRV replication (Figure 5C). We also used Dynasore (dynamin GTPase inhibitor) and Cytochalasin D (actin polymerization inhibitor) to block CME. Consistent with this, inhibition of the final stages of CME was accompanied by decreased PRV replication (Figure 5D). Moreover, CPZ and PAO administration could also achieve protection against viral infection in $\mathrm{NPC} 1{ }^{\mathrm{WT}}$ cells, but did not lead to an additive inhibitory effect on viral replication in $\mathrm{NPC}^{\mathrm{KO}}$ cells (Figure $5 \mathrm{E}$ ), as is expected of CME inhibitors and NPC1-deficiency that inhibit the same steps of the same pathway. Collectively, these findings indicate a role for CME in NPC1-dependent viral entry.

\section{U18666A blocks CME by interfering with the dynamics of CCPs}

To investigate the localization of $\mathrm{CME}$ and rule out possible interference by U18666A, the subcellular localization and distribution of AP2 protein, a component of CME on the PM, was examined. No significant changes were observed in the localization or number of AP2B1 puncta after U18666A application (Figure 6A), indicating the steady-state distribution of AP2 was not dramatically altered by U18666A 


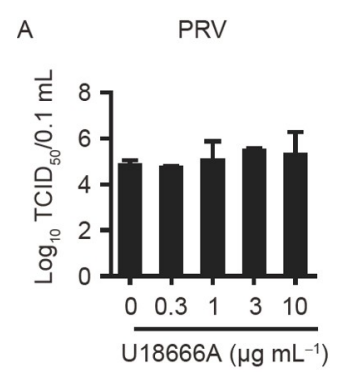

E

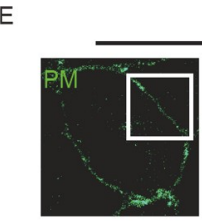

Vehicle

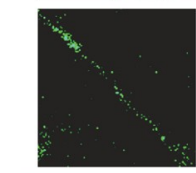

G
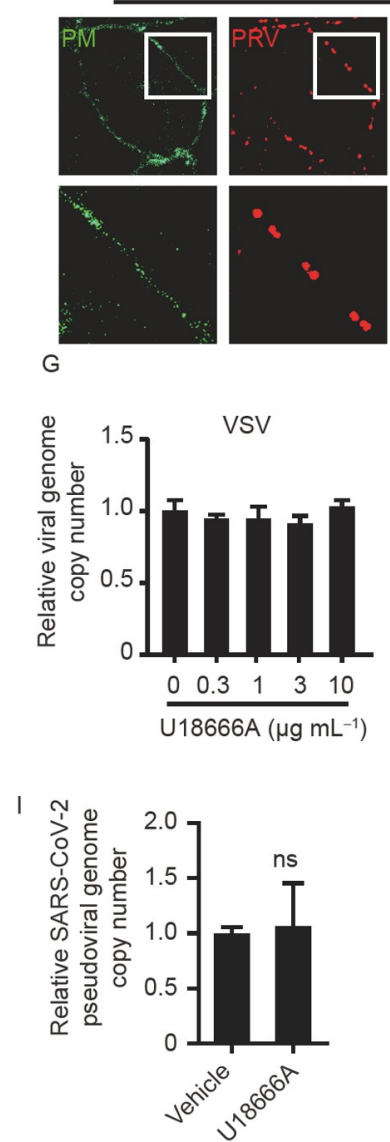
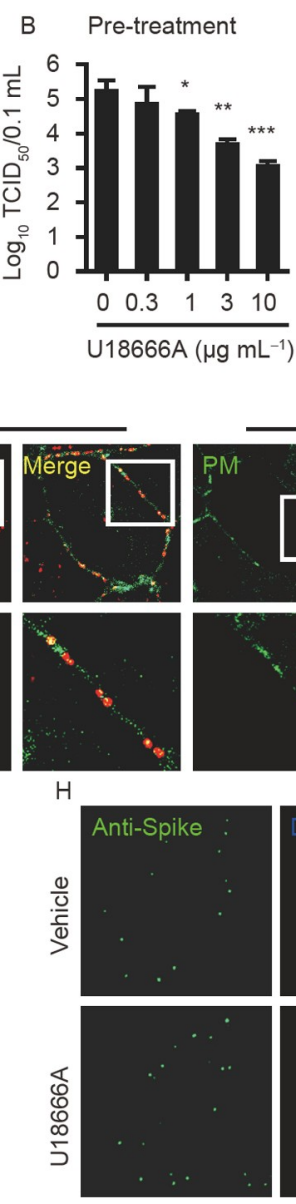

J
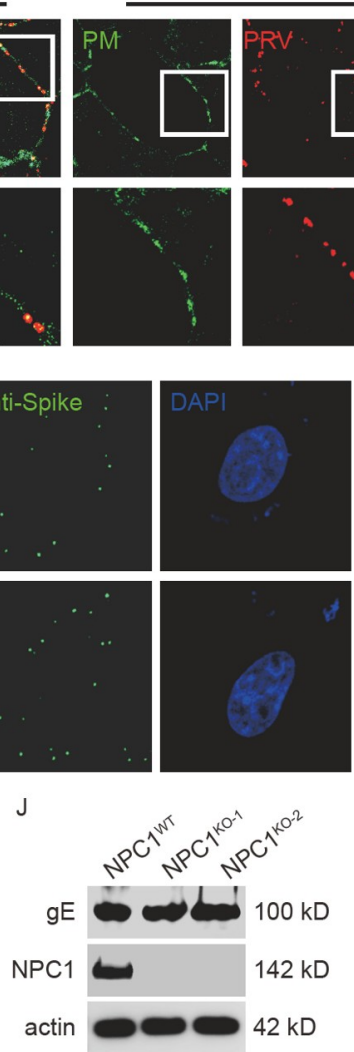

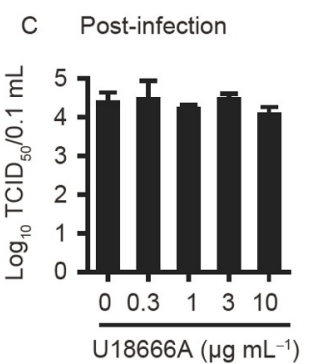

U18666A
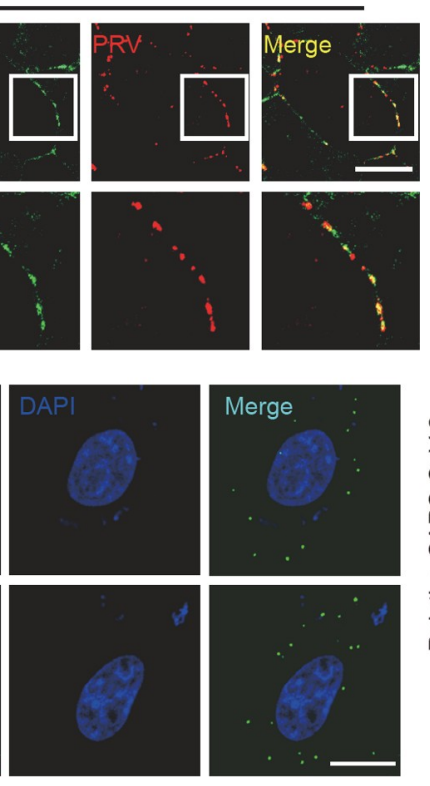

$\mathrm{K}$

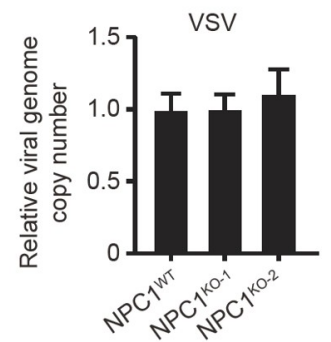

Figure 3 Inhibition of NPC1 does not affect viral attachment. A, PRV HN1201 was pre-incubated with different concentrations of U18666A for 2 h at room temperature, washed with PBS, and then subjected to repurification by centrifugation through an ultrafiltration spin-column. The repurified viruses were used to infect PK-15 cells, and the viral titers were determined by $\mathrm{TCID}_{50}$ assays. B, PK-15 cells were pretreated with different concentrations of $\mathrm{U} 18666 \mathrm{~A}$ at $37^{\circ} \mathrm{C}$ for $4 \mathrm{~h}$, then infected with PRV HN1201 (MOI=0.1) for $24 \mathrm{~h}$ without inhibitor. Virus was harvested by three freeze-thaw cycles and the viral titer was determined by a TCID 50 assay. C, Pre-cooled PK-15 cells were incubated with PRV HN1201 (MOI=0.1) at $4{ }^{\circ} \mathrm{C}$ for $2 \mathrm{~h}$ without inhibitor, and then the infectious inoculum was replaced with growth medium containing U18666A at the indicated concentrations for 24 h. The viral titer was determined by a $\mathrm{TCID}_{50}$ assay. D, PK-15 cells were treated with vehicle or U18666A for $4 \mathrm{~h}$, then infected with PRV $\mathrm{HN} 1201$ (MOI=0.1) at $4{ }^{\circ} \mathrm{C}$ for $2 \mathrm{~h}$ to analyze the viral genomic DNA by qRT-PCR. E, PK-15 cells were treated with vehicle or U18666A for 4 h, then infected with PRV HN1201 (MOI=10, viral DNA labeled with EdU) at $4^{\circ} \mathrm{C}$ for $2 \mathrm{~h}$. Cells were stained with Apollo (PRV) and CellMask ${ }^{\mathrm{TM}}$ Green (PM). The labeled viruses (red) attached to membranes of the host cells were analyzed by confocal microscopy. Scale bar, $10 \mu \mathrm{m}$. F, PK-15 cells were treated as in (E) to detect the PRV-positive cells (red) by flow cytometry. $\mathrm{G}, \mathrm{PK}-15$ cells were treated with vehicle or U18666A for $4 \mathrm{~h}$, then infected with VSV-GFP (MOI=0.01) at $4^{\circ} \mathrm{C}$ for $2 \mathrm{~h}$ to analyze the viral genomic RNA by qRT-PCR. H, Vero cells were treated with vehicle or U18666A for $4 \mathrm{~h}$, then infected with SARS-CoV-2 pseudovirus at $4{ }^{\circ} \mathrm{C}$ for 2 h. Cells were fixed with $4 \%$ PFA, and the viral spike protein was detected with the anti-spike antibody. Data were analyzed using ImageJ software. Scale bar, $10 \mu \mathrm{m}$. I, Vero cells were treated with vehicle or U18666A for $4 \mathrm{~h}$, then infected with SARS-CoV-2 pseudovirus at $4^{\circ} \mathrm{C}$ for $2 \mathrm{~h}$ to analyze the viral genomic RNA by qRT-PCR. J, $\mathrm{NPC}^{\mathrm{WT}}$ and NPC1 ${ }^{\mathrm{KO}} \mathrm{PK}-15$ cells were incubated with PRV HN1201 (MOI=10) at $4^{\circ} \mathrm{C}$ for $2 \mathrm{~h}$. The viral envelope protein gE attached to cells was analyzed by immunoblotting. K, NPC1 ${ }^{\mathrm{WT}}$ and $\mathrm{NPC} 1^{\mathrm{KO}} \mathrm{PK}-15$ cells were incubated with VSV-GFP (MOI $=0.01$ ) at $4^{\circ} \mathrm{C}$ for $2 \mathrm{~h}$. The viral genomic RNA on cells was analyzed by qRT-PCR. *, $P<0.05$; **, $P<0.01$; ***, $P<0.001$; ns, not significant; one-way ANOVA.

treatment. Next, we incubated PK- 15 cells with PRV at $4{ }^{\circ} \mathrm{C}$ to allow for the accumulation of PRV in CCPs. As shown in Figure 6B, U18666A administration caused no noticeable difference in PRV accumulation, suggesting that U18666A does not interfere with PRV recognition or sequestration into CCPs, a step mediated by endocytic adaptors such as AP2 
A

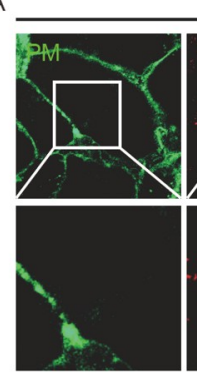

C

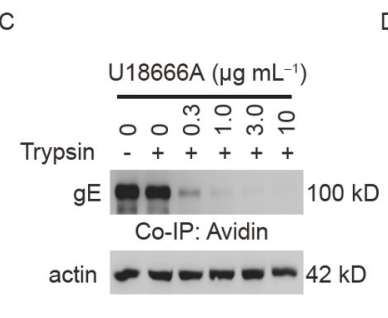

Vehicle
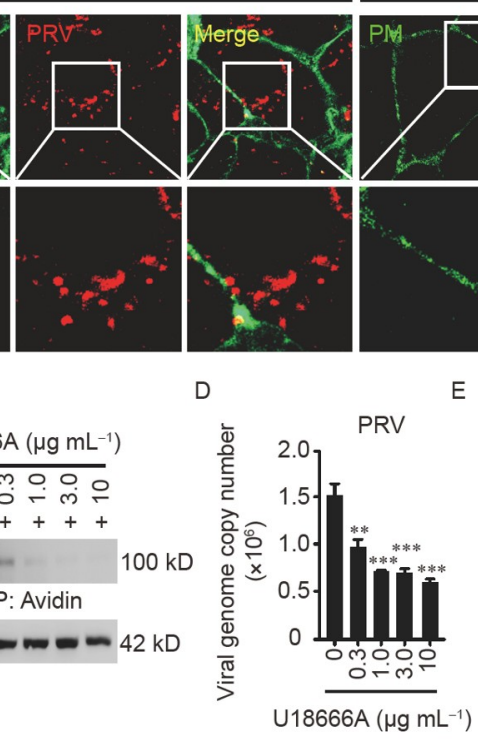

U18666A

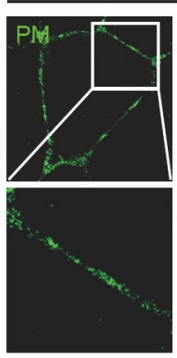

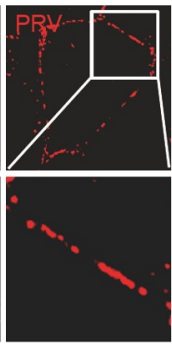

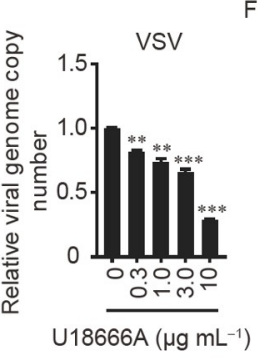

F
B
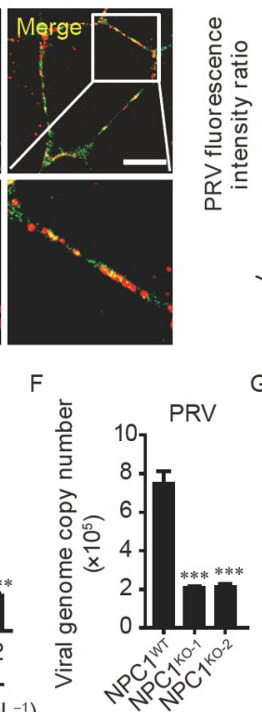

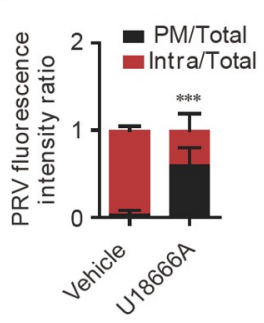

G

$$
\mathrm{H}
$$
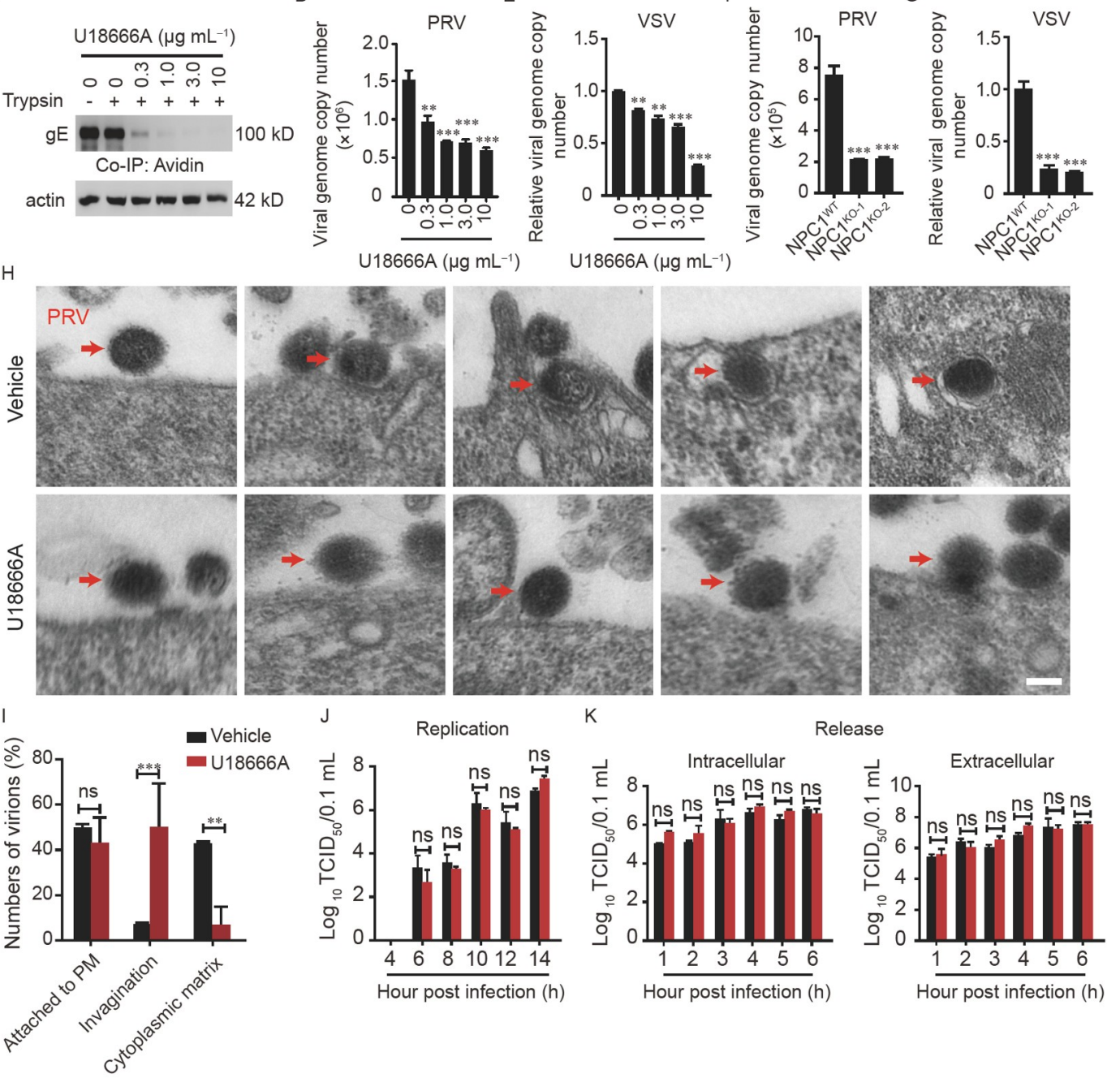

Figure 4 Inhibition of NPC1 influences viral entry. A, PK-15 cells were treated with vehicle or U18666A for 4 h, then infected with EdU-labeled PRV $\mathrm{HN} 1201(\mathrm{MOI}=10)$ at $4^{\circ} \mathrm{C}$ for $2 \mathrm{~h}$ before shifting the temperature to $37^{\circ} \mathrm{C}$ for 15 min to facilitate viral entry. Cells were stained with Apollo (PRV) and CellMask ${ }^{\mathrm{TM}}$ Green (PM) to analyze fluorescence by confocal microscopy. Scale bar, $10 \mu \mathrm{m}$. B, ImageJ quantification of the fluorescence intensity ratio in cells from (A). C, PK-15 cells were treated with U18666A for $4 \mathrm{~h}$ followed by PRV HN1201 (MOI=10) infection at $4{ }^{\circ} \mathrm{C}$ for $2 \mathrm{~h}$, and then the temperature was shifted to $37^{\circ} \mathrm{C}$ for $30 \mathrm{~min}$ to allow viral entry. Cells were collected to analyze the remaining PRV gE in the PM by a cell surface biotinylation assay. D and E, PK-15 cells were treated with U18666A for $4 \mathrm{~h}$ followed by PRV HN1201 (D, MOI=0.1) or VSV-GFP (E, MOI $=0.01$ ) infection at $4^{\circ} \mathrm{C}$ for $2 \mathrm{~h}$, and then the temperature was shifted to $37^{\circ} \mathrm{C}$ for 60 min to check the viral genome by qRT-PCR. F and G, NPC1 ${ }^{\text {WT }}$ and NPC1 ${ }^{\mathrm{KO}} \mathrm{PK}-15$ cells were infected with PRV $\mathrm{HN} 1201(\mathrm{~F}, \mathrm{MOI}=0.1)$ or VSV-GFP $(\mathrm{G}, \mathrm{MOI}=0.01)$ at $4^{\circ} \mathrm{C}$ for $2 \mathrm{~h}$, and then the temperature was shifted to $37^{\circ} \mathrm{C}$ for 60 min to check the viral genome by qRT-PCR. H, PK-15 cells were treated with U18666A $\left(10 \mu \mathrm{g} \mathrm{mL}{ }^{-1}\right)$ for $4 \mathrm{~h}$ followed by infection with PRV $\mathrm{HN} 1201(\mathrm{MOI}=100)$ at $4^{\circ} \mathrm{C}$ for $2 \mathrm{~h}$, then the temperature was shifted to $37^{\circ} \mathrm{C}$ for $10 \mathrm{~min}$ to check viral entry by transmission electron microscopy. Red arrows indicate the virus particles. Scale bar, $200 \mathrm{~nm}$. I, Transmission electron microscopy quantification of virions in different stages of entry from (H). J, PK-15 cells were infected with PRV HN1201 $(\mathrm{MOI}=1)$ at $4^{\circ} \mathrm{C}$ for $2 \mathrm{~h}$ before shifting the temperature to $37^{\circ} \mathrm{C}$ for $1 \mathrm{~h}$ to allow viral entry, then cells were replaced with vehicle or $\mathrm{U} 18666 \mathrm{~A}\left(10 \mu \mathrm{g} \mathrm{mL}^{-1}\right)$ for $4,6,8,10,12$, or $14 \mathrm{~h}$. The viral titer was determined by a $\mathrm{TCID}_{50}$ assay. K, PK-15 cells were infected with PRV $\mathrm{HN} 1201$ (MOI=1) at $4{ }^{\circ} \mathrm{C}$ for $2 \mathrm{~h}$ before shifting the temperature to $37^{\circ} \mathrm{C}$ for $12 \mathrm{~h}$. After $12 \mathrm{~h}$, the cells were replaced with a vehicle or U18666A (10 $\left.\mu \mathrm{g} \mathrm{mL}^{-1}\right)$ for $1-6 \mathrm{~h}$. The supernatants and intracellular viral fluids were collected at different time points, and the viral titers were determined by a TCID 50 assay. $* *, P<.01$; $* * *, P<0.001 ;$ ns, not significant; one-way ANOVA. 

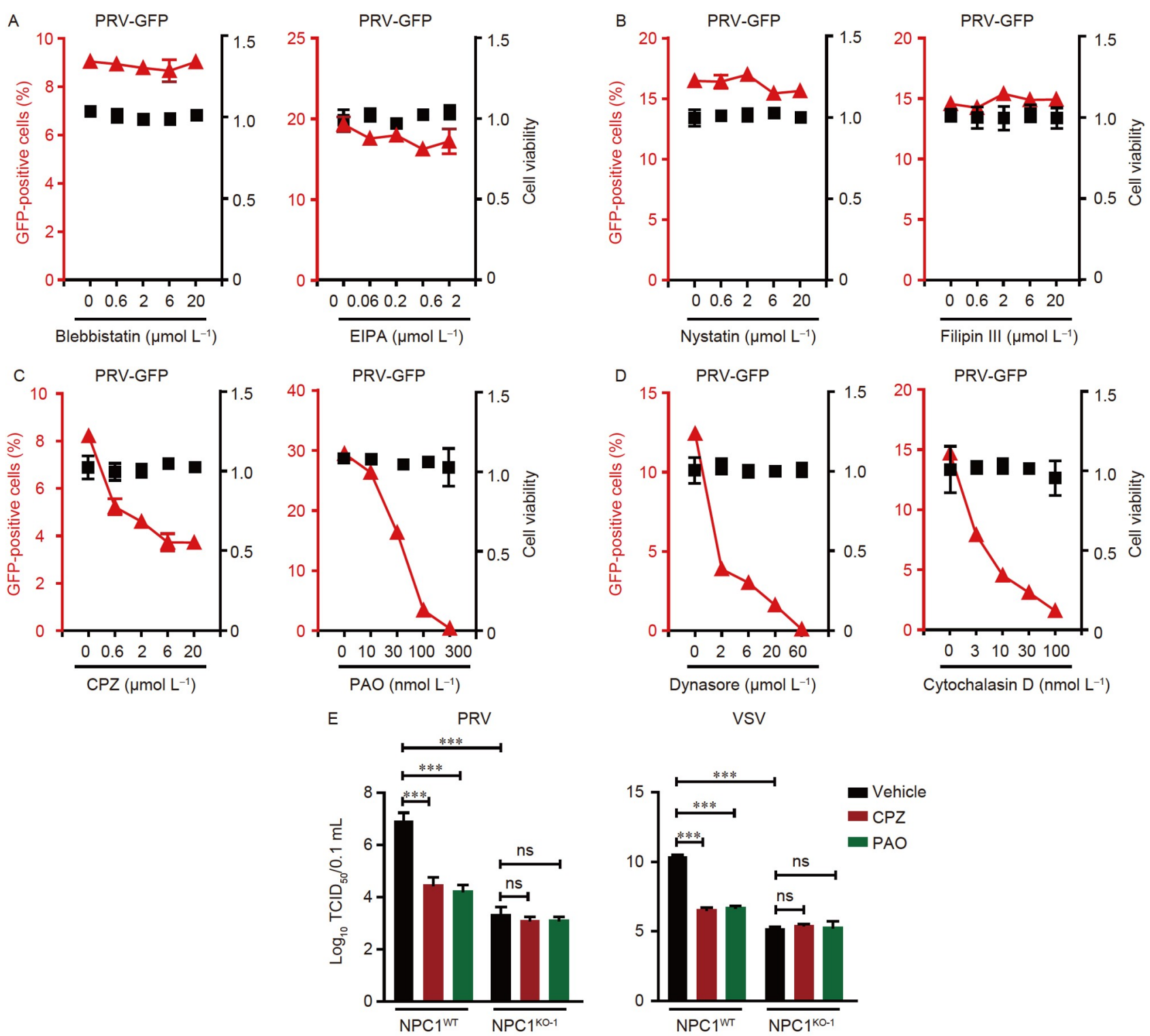

Figure 5 NPC1-dependent viral entry relies on CME. A-D, PK-15 cells were treated with Blebbistatin $\left(0-20 \mu \mathrm{mol} \mathrm{L}^{-1}\right), \mathrm{EIPA}^{-1}\left(0-2 \mu \mathrm{mol} \mathrm{L}{ }^{-1}\right), \mathrm{Nystatin}^{-1}$ $\left(0-20 \mu \mathrm{mol} \mathrm{L}^{-1}\right)$, Filipin III $\left(0-20 \mu \mathrm{mol} \mathrm{L}^{-1}\right)$, CPZ $\left(0-20 \mu \mathrm{mol} \mathrm{L}^{-1}\right)$, PAO $\left(0-300 \mathrm{nmol} \mathrm{L}^{-1}\right)$, Dynasore $\left(0-60 \mu \mathrm{mol} \mathrm{L}^{-1}\right)$, or Cytochalasin D $\left(0-100 \mathrm{nmol} \mathrm{L}^{-1}\right)$ for $4 \mathrm{~h}$, followed by PRV-GFP (MOI=0.01) infection in the continued presence of inhibitors to detect the GFP-positive cells by flow cytometry (red), or to check cell viability by a CCK- 8 assay (black). E, NPC1 ${ }^{\text {WT }}$ and NPC1 ${ }^{\mathrm{KO}} \mathrm{PK}-15$ cells were treated with CPZ $\left(20 \mu \mathrm{mol} \mathrm{L}^{-1}\right)$ or PAO $\left(300 \mathrm{nmol} \mathrm{L}^{-1}\right)$ for $4 \mathrm{~h}$, then infected with PRV HN1201 (MOI=1) or VSV-GFP (MOI=0.001) for $24 \mathrm{~h}$ to determine the viral titer by a TCID $_{50}$ assay. $* * *, P<0.001$; ns, not significant; one-way ANOVA.

(Edeling et al., 2006). A temperature shift from $4^{\circ} \mathrm{C}$ to $37^{\circ} \mathrm{C}$ induces the internalization of the virus (Tscherne et al., 2006), which is accompanied by CCP maturation and clathrin recruitment. A co-immunoprecipitation (Co-IP) assay demonstrated that even after the temperature shifted to $37^{\circ} \mathrm{C}$ at a time corresponding to an authentic PRV infection, U18666A did not affect the binding of PRV $\mathrm{gE}$ to AP2M1 (Figure 6C). Additionally, using a cell surface biotinylation assay, we confirmed again that U18666A, like CPZ (representative CME inhibitor), had no effect on the interaction between PRV virions and CME component, but inhibited the endocytosis of the virus (Figure 6D).
CME is the leading portal of entry into cells for many molecules and cell surface-bound cargoes. During this process, sorting signals in the transmembrane cargo are recognized by AP2, triggering the recruitment of cytosolic coat proteins to a budding vesicle, CCPs are then formed that capture the protein cargo, invaginate, and then pinch off to form clathrin-coated vesicles (CCVs) (Mettlen et al., 2018). We noticed that, in HeLa cells, U18666A dramatically blocked transferrin (a ligand for CME) endocytosis (Figure S5A and B in Supporting Information). We speculated that the inhibitory effect of U18666A on CME might be attributable to a failure of CCPs to detach from the PM. To assess 

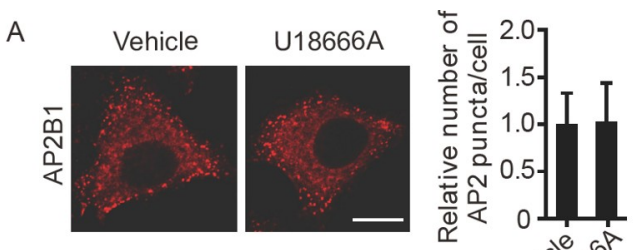

B
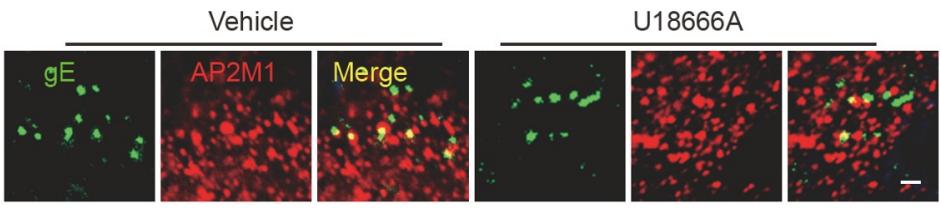

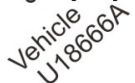

C

PRV $\frac{0}{--+} \frac{5}{--+} \frac{15}{--+} \frac{30 \mathrm{~min}}{--+} \frac{0}{--+} \frac{5}{--+} \frac{15}{-+++}$

AP2M1-FLAG +-++-++-++-+++-++-++-++-++

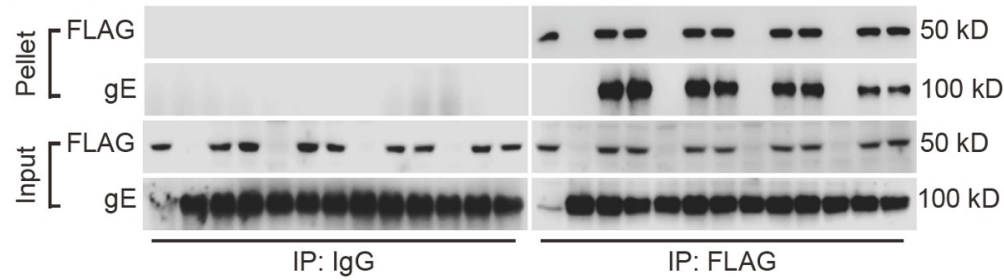

$I P: \lg G$

P: FLAG

$E$
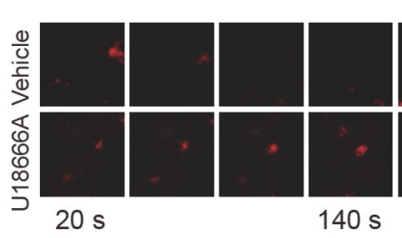

Clathrin-coated pits

G
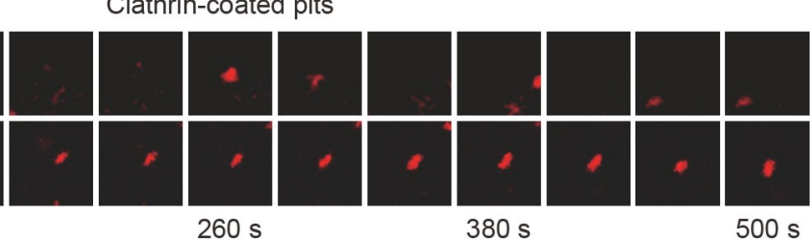

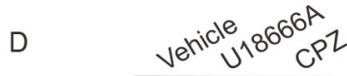
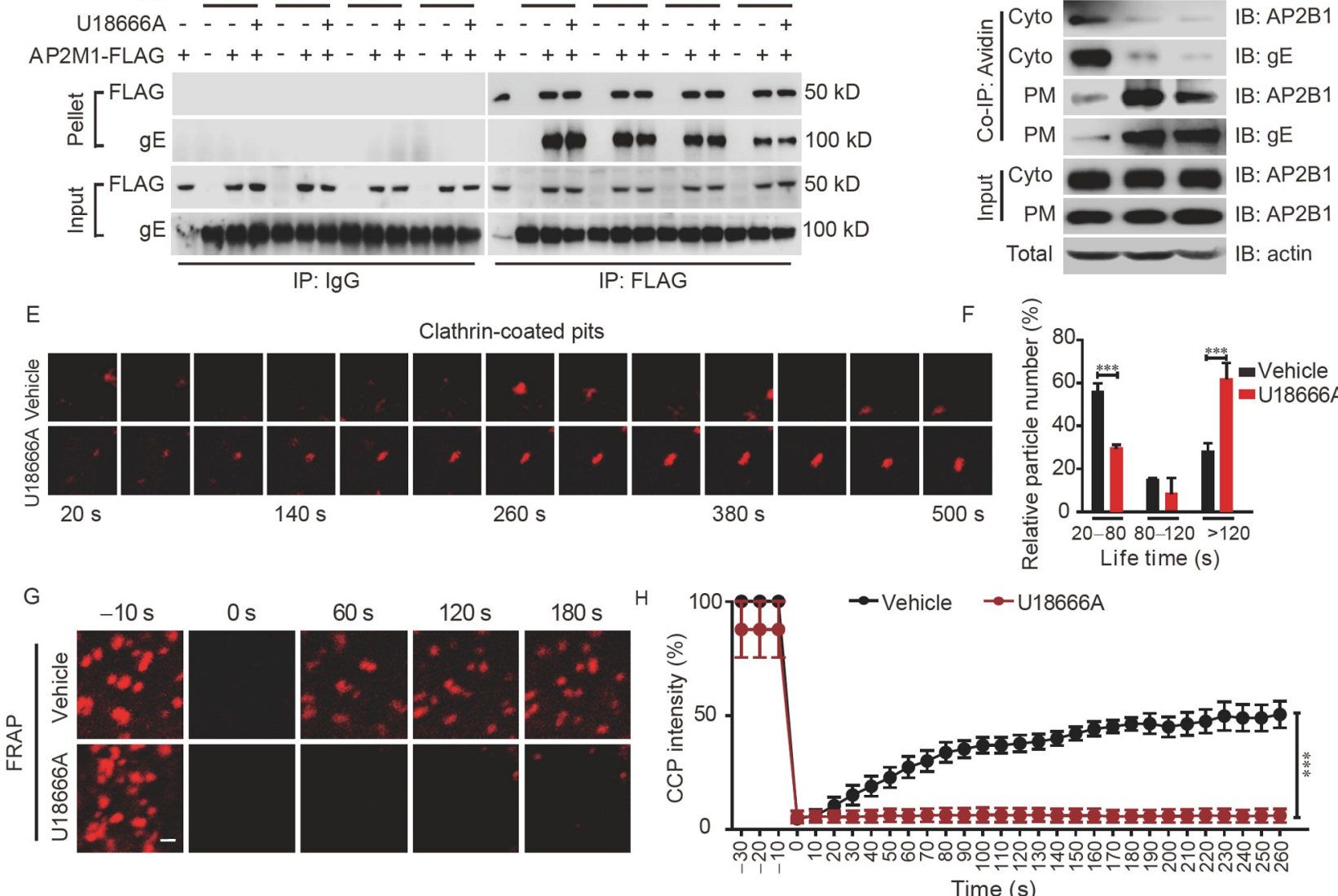

Figure 6 U18666A does not affect the interaction between PRV and CCPs. A, HeLa cells were transfected with AP2B1-mCherry for $24 \mathrm{~h}$ followed by vehicle or U18666A $\left(10 \mu \mathrm{g} \mathrm{mL}^{-1}\right)$ treatment for another $24 \mathrm{~h}$ to observe the distribution of AP2B1 by confocal microscopy. Scale bar, $10 \mu \mathrm{m}$. Quantification of the relative number of AP2B1 puncta per cell is shown on the right. B, PK-15 cells were treated with U18666A $\left(10 \mu \mathrm{g} \mathrm{mL} \mathrm{L}^{-1}\right)$ for $4 \mathrm{~h}$ followed by PRV $\mathrm{HN} 1201$ (MOI=10) infection at $4^{\circ} \mathrm{C}$ for $2 \mathrm{~h}$, then the temperature was shifted to $37^{\circ} \mathrm{C}$ for 30 min to check the co-localization between PRV gE and AP2M1 by an immunofluorescence assay. Scale bar, $1 \mu \mathrm{m}$. C, HeLa cells transfected with the indicated plasmids for $24 \mathrm{~h}$ were treated with vehicle or U18666A $\left(10 \mu \mathrm{g} \mathrm{mL}^{-1}\right)$ for $4 \mathrm{~h}$, followed by PRV HN1201 (MOI=20) at $4^{\circ} \mathrm{C}$ for $2 \mathrm{~h}$, then the temperature was shifted to $37^{\circ} \mathrm{C}$ for $0-30$ min to check the interaction of PRV gE with AP2M1 by a Co-IP assay. D, PK-15 cells were treated with U18666A $\left(10 \mu \mathrm{g} \mathrm{mL}^{-1}\right)$ or CPZ $\left(20 \mu \mathrm{mol} \mathrm{L}{ }^{-1}\right)$ for $4 \mathrm{~h}$ followed by PRV HN1201 (MOI=10) infection at $4^{\circ} \mathrm{C}$ for $2 \mathrm{~h}$, then the temperature was shifted to $37^{\circ} \mathrm{C}$ for 30 min to analyze PRV gE internalization by a cell surface biotinylation assay. E, HeLa cells were transfected with AP2B1-mCherry plasmid for $24 \mathrm{~h}$ followed by vehicle or U18666A $\left(1 \mu \mathrm{g} \mathrm{mL} \mathrm{L}^{-1}\right)$ treatment for $8 \mathrm{~h}$ to estimate the dynamics of CCPs in living cells by time-lapse confocal microscopy. F, The pooled lifetime distribution of CCPs depicted in (E) ( $n=10)$. Values were determined from the time between the appearance and disappearance of AP2B1 puncta. G, HeLa cells were transfected and treated as in (E), and the dynamics of CCPs were assessed by FRAP. Scale bar, $1 \mu \mathrm{m}$. H, Quantification of the relative fluorescent intensity of AP2B1 puncta in the FRAP region over time from (G) $(n=10) . * *, P<0.001$; one-way ANOVA.

this hypothesis, we studied CCP dynamics in more detail.

Live HeLa cells expressing AP2B1-mCherry were monitored by confocal microscopy. Consistent with previous reports (Ehrlich et al., 2004), AP2B1-containing CCPs change over time as CCPs bud and detach (spots disappear), and new pits are formed (spots appear) at the PM, with most events exhibiting lifetimes between 20 and $80 \mathrm{~s}$. A smaller fraction of long-lived AP2B1-mCherry clusters were de- tected with lifetimes of more than $90 \mathrm{~s}$. U18666A led to a dramatic shift toward long-lived AP2B1-mCherry clusters, many of which exhibited lifetimes well beyond $120 \mathrm{~s}$ (Figure $6 \mathrm{E}$ ), which is different from the results of kymographs and cumulative plots of CCP lifetimes (Figure 6F). To further corroborate the role of U18666A in CCP dynamics, fluorescence recovery after photobleaching (FRAP) was paired with live-cell confocal microscopy imaging. Following the 
$20 \mathrm{~s}$ bleaching laser pulse, AP2B1-mCherry fluorescence rapidly recovered to about $30 \%$ of its initial value at approximately $60 \mathrm{~s}$ in control cells, while U18666A-treated cells did not show any recovery of AP2B1-mCherry fluorescence within $180 \mathrm{~s}$ (Figure 6G and H). Collectively, these findings indicate that U18666A blocks CME by interfering with CCP dynamics.

\section{U18666A inhibits CCP dynamic-dependent viral entry by perturbing cholesterol levels in the $P M$}

NPC1 is a lysosomal membrane protein that exports LDLderived cholesterol to other cellular sites such as the PM. The lysosomal egress of cholesterol can be blocked by exposure to U18666A, which explicitly targets NPC1 (Lu et al., 2015). In the PM, cholesterol is necessary for modulating membrane fluidity and participating in the regulation of membrane dynamics and trafficking (Subtil et al., 1999). To explore whether the blocking of cholesterol transport by U18666A treatment or NPC1 deficiency plays a critical role in CCP dynamics during viral entry, we developed a cholesterol complementation assay. U18666A treatment reduced PM-cholesterol relative to vehicle-treated cells. After replenishment, cholesterol levels were restored to a level similar to that in control cells (Figure S6A-C in Supporting Information).

Next, CCP dynamics were measured in U18666A (cholesterol-depleted) and U18666A+chol (cholesterol-replenished) cells. Both the lifetimes of AP2B1-mCherrycontaining puncta (Figure 7A and B) and the recovery of AP2B1-positive spots (Figure S6D and E in Supporting Information) were complemented by adding exogenous cholesterol to U18666A-treated cells. Similarly, U18666A treatment trapped PRV particles with AP2B1 structures at the $\mathrm{PM}$, which can be complemented by the addition of exogenous cholesterol (Figure 7C; Figure S6F and Movie S1-S3 in Supporting Information). Moreover, a previous report indicated that binding of SARS-CoV-2 spike protein to angiotensin-converting enzyme 2 (ACE2) triggers membrane fusion and viral entry into the host cell (Hoffmann et al., 2020). We found that the internalization of ACE2 with AP2B1 structures under the stimulation of spike protein could also be restored by cholesterol replenishment (Figure 7D; Figure S6G and Movie S4-S6 in Supporting Information). Thus, although $\mathrm{CCP}$ dynamics required for viral entry are affected by U18666A, this can be supplanted by the addition of cholesterol.

We next tested whether replenishment of exogenous cholesterol could restore U18666A-mediated inhibition of PRV infectivity. As shown in Figure 8A and B, U18666A treatment significantly reduced EdU-labeled PRV genome internalization, but the addition of soluble cholesterol restored this inhibitory effect. A cell surface biotinylation assay also confirmed that U18666A-induced PRV entry defects could be complemented by the addition of cholesterol (Figure 8C and D). Similarly, in Figures 8E and Figure S6H in Supporting Information, replenishment with cholesterol, also resumed the entry of SARS-CoV-2 pseudovirus. Remarkably, supplementation with soluble cholesterol restored the entry of PRV and VSV into NPC1 ${ }^{\mathrm{KO}} \mathrm{PK}-15$ cells, where lysosomal egress of cholesterol was blocked, resulting in a distinct increase in both viral genome number and titer (Figure $8 \mathrm{~F}-\mathrm{I}$ ). Together, the data indicate that the primary function of U18666A or NPC1 deficiency in broad-spectrum antivirals relies on the regulation of cholesterol transport.

\section{U18666A exhibits broad-spectrum antiviral effects in vivo}

It is a huge challenge for the host to defend against viruses, and we investigated whether U18666A could be used to protect against virus infection in vivo. The potential toxicity of U18666A was first assessed. Body weights (Figure S7A in Supporting Information), alanine aminotransferase (ALT) and aspartate aminotransferase (AST) serum levels (Figure S7B in Supporting Information), and organ toxicology tests (Figure S7C in Supporting Information) were conducted in mice injected via the intraperitoneal (i.p.) route with U18666A (once every $3 \mathrm{~d}$ ) solubilized in PBS (up to $50 \mathrm{mg} \mathrm{kg}^{-1}$ ) for $12 \mathrm{~d}$. The results revealed no abnormalities in the treated group compared with the vehicle control group. However, the repetitive administration of high dose U18666A in rats was reported to induce epileptic symptoms (Cenedella et al., 1982). To avoid such adverse effects, we gave up the highest concentration of $50 \mathrm{mg} \mathrm{kg}^{-1}$ and tested the antiviral effect of different injection doses $\left(0-30 \mathrm{mg} \mathrm{kg}^{-1}\right)$, and found that the protection rate of $30 \mathrm{mg} \mathrm{kg}^{-1}$ can reach to $60 \%$ (Figure S7D in Supporting Information). Therefore, we chose this concentration for further research.

We examined the antiviral activity of U18666A against lethal challenge with PRV HN1201. Mice were challenged with $1 \times 10^{6} \mathrm{TCID}_{50}$ of PRV HN1201, then after $10 \mathrm{~d}$, when the animals no longer died, mice were euthanized under ether anesthesia. Over the 10-day period, 11/12 mice (92\%) survived after receiving two intraperitoneally (i.p.) injections of U18666A, whereas only 6/12 (50\%) vehicle PBS-treated mice survived (Figure 9A). Virus-induced cytokines play a significant role in recruiting leukocytes to the site of infection and activating innate immune responses to induce inflammation. Despite their protective role, severe inflammation can also be induced by a cytokine storm. Mice in the U18666A-treated group exhibited significantly reduced serum IL- $1 \beta$ and IFN- $\beta$ concentrations (Figure 9B), which was accompanied by decreased IL- $1 \beta$ and IFN- $\beta$ gene expression and a reduction in PRV load in the lungs (Figure 
A

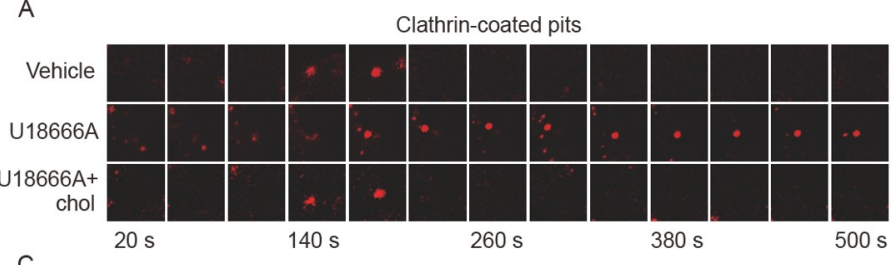

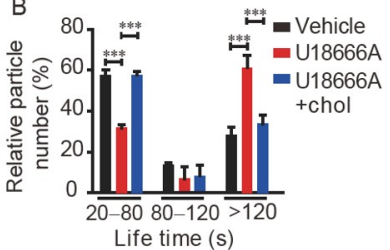

C
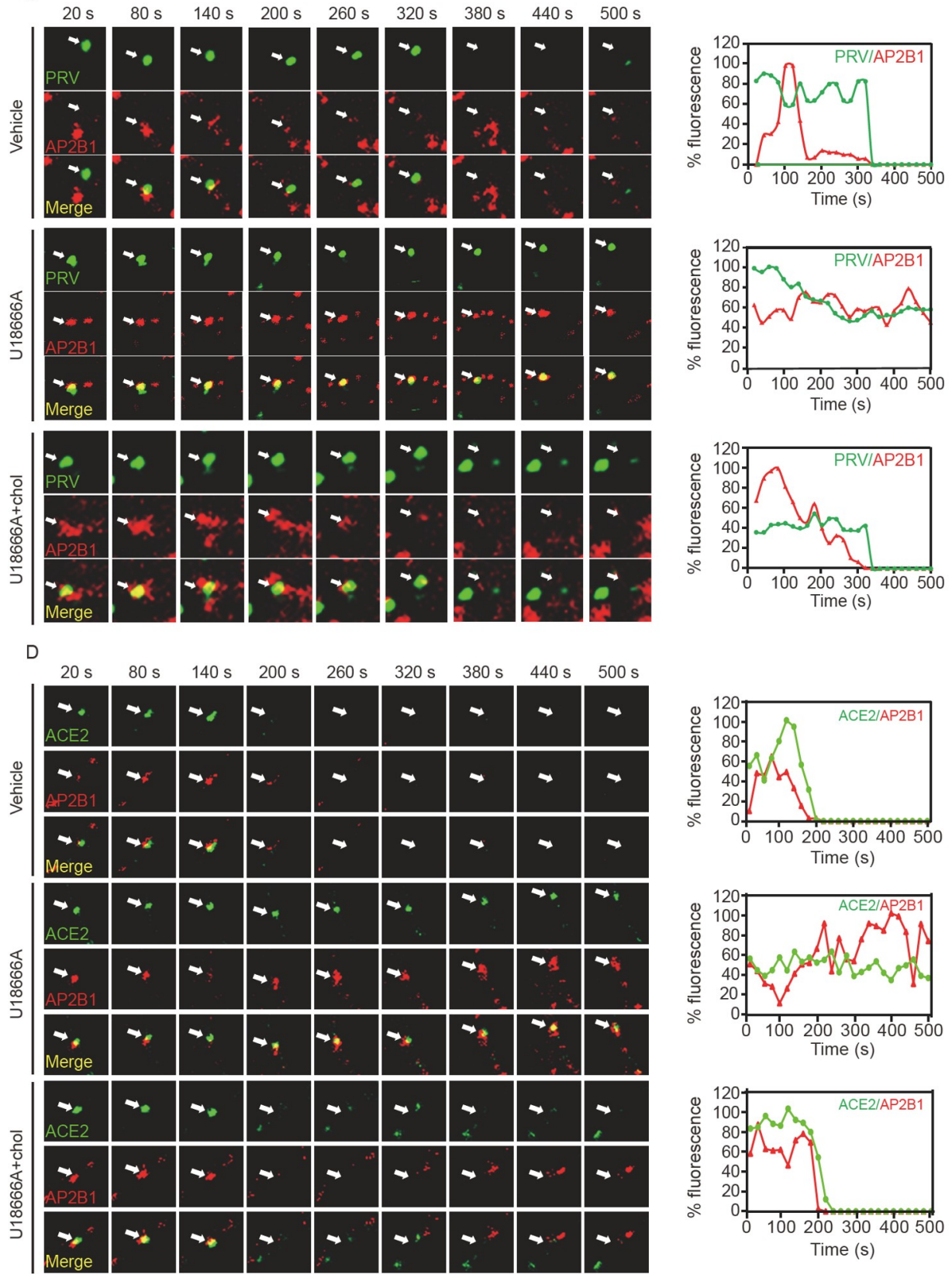

Figure 7 U18666A-affected CCP dynamics for viral entry restored by cholesterol replenishment. A, HeLa cells were transfected with AP2B1-mCherry plasmid for $24 \mathrm{~h}$ followed by vehicle, U18666A $\left(1 \mu \mathrm{g} \mathrm{mL} \mathrm{m}^{-1}\right)$, or U18666A + chol $\left(1 \mu \mathrm{g} \mathrm{mL} \mathrm{U}^{-1} \mathrm{U}_{18666 \mathrm{~A}}\right.$ plus $0.003 \mu \mathrm{g} \mathrm{mL} \mathrm{L}^{-1}$ cholesterol) treatment for $8 \mathrm{~h}$ to estimate the dynamics of CCPs in living cells by time-lapse confocal microscopy. B, The pooled lifetime distribution of CCPs depicted in (A) ( $n=10$ ). Values were determined from the time between the appearance and disappearance of AP2B1 puncta. C, HeLa cells transfected with AP2B1-mCherry plasmid were treated with vehicle, U18666A $\left(1 \mu \mathrm{g} \mathrm{mL}^{-1}\right)$, or U18666A+chol $\left(1 \mu \mathrm{g} \mathrm{mL}{ }^{-1} \mathrm{U} 18666 \mathrm{~A}\right.$ plus $0.003 \mu \mathrm{g} \mathrm{mL} \mathrm{mol}^{-1}$ chosterol) for $8 \mathrm{~h}$ followed by infection with Alexa Fluor 488-conjugated PRV HN1201 (MOI=10) at $4{ }^{\circ} \mathrm{C}$ for $2 \mathrm{~h}$, then the temperature was shifted to $37^{\circ} \mathrm{C}$ to observe the movement of virus associated with AP2B1 puncta. The relative fluorescence intensity of AP2B1 and PRV was quantified by ImageJ software. The peak fluorescence was set to 1. D, ACE2GFP- and AP2B1-mCherry-expressing HeLa cells were treated with vehicle, U18666A $\left(1 \mu \mathrm{g} \mathrm{mL}^{-1}\right)$, or U18666A+chol $\left(1 \mu \mathrm{g} \mathrm{mL} \mathrm{U}^{-1} \mathrm{U} 18666 \mathrm{~A}\right.$ plus $0.003 \mu \mathrm{g} \mathrm{mL}^{-1}$ cholesterol) for $8 \mathrm{~h}$ followed by incubation with SARS-CoV-2 spike protein $(100 \mu \mathrm{g})$ at $4^{\circ} \mathrm{C}$ for $2 \mathrm{~h}$, then the temperature was shifted to $37^{\circ} \mathrm{C}$ to observe the internalization of ACE2 associated with AP2B1 puncta. The relative fluorescence intensity of ACE2 and AP2B1 was quantified by ImageJ software. The peak fluorescence was set to 1 . ***, $P<0.001$, one-way ANOVA. 
A Vehicle U18666A U18666A+chol
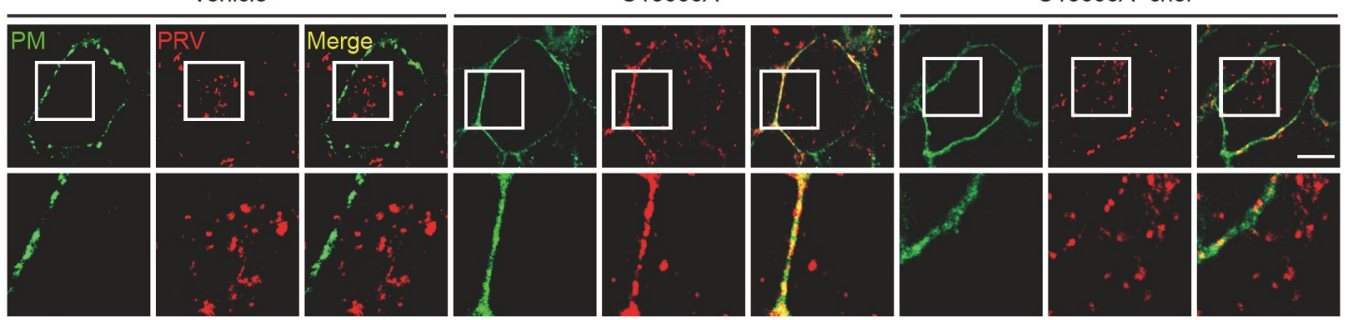

B
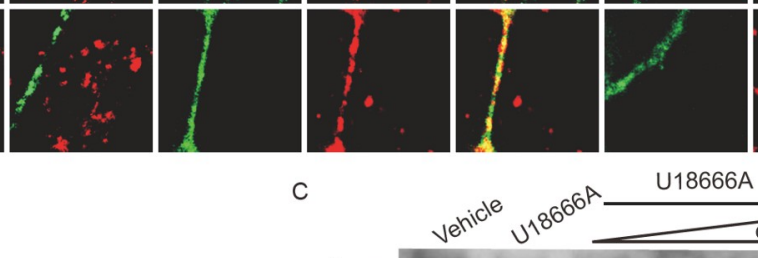

U18666A

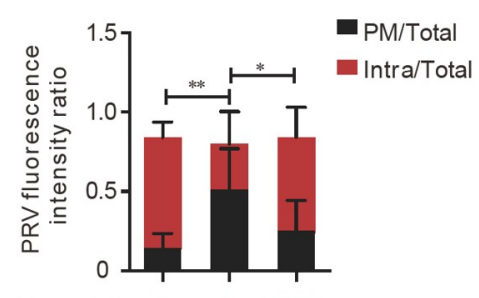

chol $\left(\mu \mathrm{g} \mathrm{mL}^{-1}\right) \quad 0 \quad 0 \quad 0.003$

$\mathrm{U} 18666 \mathrm{~A}\left(1 \mu \mathrm{g} \mathrm{mL}^{-1}\right)-\quad+\quad+$

D

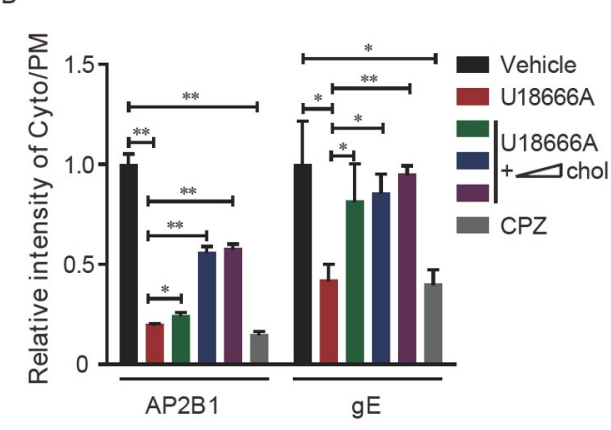

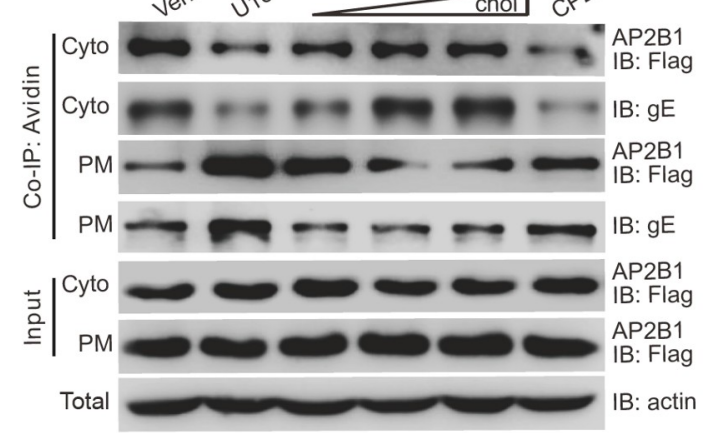

E
$\mathrm{F}$

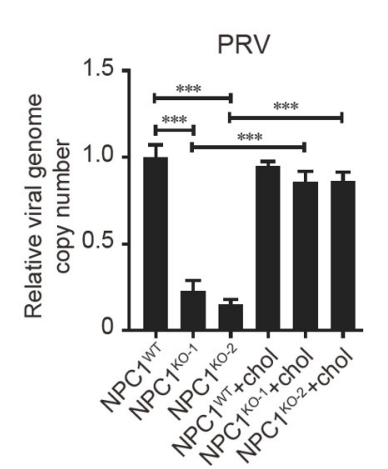

G

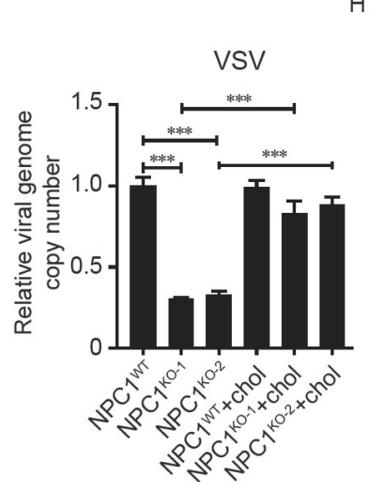

$\mathrm{H}$
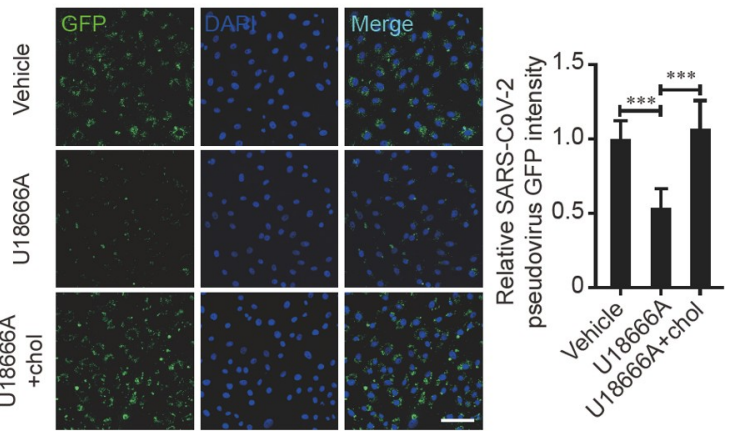
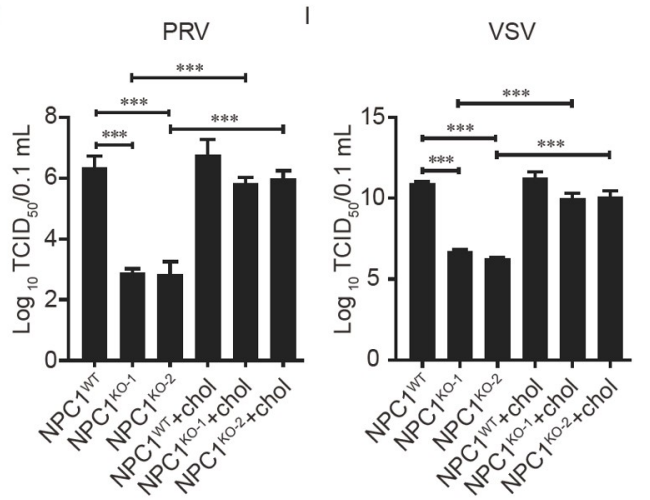

Figure 8 U18666A-induced inhibition of viral entry is rescued by cholesterol replenishment. A, PK-15 cells were treated with vehicle, U18666A $\left(1 \mu \mathrm{g} \mathrm{mL}^{-1}\right)$, or U18666A+chol $\left(1 \mu \mathrm{g} \mathrm{mL}^{-1} \mathrm{U} 18666 \mathrm{~A}\right.$ plus $0.003 \mu \mathrm{g} \mathrm{mL}{ }^{-1}$ cholesterol) for $8 \mathrm{~h}$, then infected with EdU-labeled PRV HN1201 (MOI=10) at $4^{\circ} \mathrm{C}$ for $2 \mathrm{~h}$ before shifting the temperature to $37^{\circ} \mathrm{C}$ for $15 \mathrm{~min}$. Cells were stained with Apollo (PRV) and CellMask ${ }^{\mathrm{TM}}$ Green (PM) to analyze fluorescence by confocal microscopy. Scale bar, $10 \mu \mathrm{m}$. B, ImageJ quantification of the fluorescence intensity ratio in cells from (A). C, PK-15 cells were treated with vehicle, U18666A ( $1 \mu \mathrm{g} \mathrm{mL}^{-1}$, U18666A+chol $\left(1 \mu \mathrm{g} \mathrm{mL}^{-1} \mathrm{U} 18666 \mathrm{~A}\right.$ plus $0.003,0.01,0.03 \mu \mathrm{g} \mathrm{mL}^{-1}$ cholesterol), or CPZ (20 $\left.\mu \mathrm{mol} \mathrm{L}{ }^{-1}\right)$ for $8 \mathrm{~h}$ followed by PRV $\mathrm{HN} 1201(\mathrm{MOI}=10)$ infection at $4^{\circ} \mathrm{C}$ for $2 \mathrm{~h}$, then the temperature was shifted to $37^{\circ} \mathrm{C}$ for $30 \mathrm{~min}$ to analyze PRV gE internalization by a cell surface biotinylation assay. D, Quantification of the relative intensity of AP2B1 and $\mathrm{gE}$ from $(\mathrm{C})$. E, Vero cells were treated with vehicle, $\mathrm{U} 18666 \mathrm{~A}\left(1 \mu \mathrm{g} \mathrm{mL}^{-1}\right)$, or $\mathrm{U} 18666 \mathrm{~A}+\mathrm{chol}\left(1 \mu \mathrm{g} \mathrm{mL}^{-1} \mathrm{U} 18666 \mathrm{~A}\right.$ plus $0.003 \mu \mathrm{g} \mathrm{mL}^{-1}$ cholesterol) for $8 \mathrm{~h}$, then infected with SARS-CoV-2 pseudovirus and simultaneously treated with the indicated compounds for $24 \mathrm{~h}$. Cells were fixed with $4 \%$ PFA, and the GFP fluorescence was examined by confocal microscopy. Scale bar, $100 \mu \mathrm{m}$. Data were analyzed using ImageJ software. F and $\mathrm{G}, \mathrm{NPC}^{\mathrm{WT}}$ and $\mathrm{NPC} 1^{\mathrm{KO}} \mathrm{PK}-15$ cells were treated with vehicle or cholesterol $\left(0.003 \mu \mathrm{g}\right.$ mL $\left.{ }^{-1}\right)$ for $4 \mathrm{~h}$ followed by PRV HN1201 (F, MOI=0.1) or VSV-GFP (G, MOI $=0.01)$ infection at $4^{\circ} \mathrm{C}$ for $2 \mathrm{~h}$, then the temperature was shifted to $37^{\circ} \mathrm{C}$ for 60 min to analyze the entry of viral genome by qRT-PCR. H and I, NPC1 ${ }^{\text {WT }}$ and $\mathrm{NPC}^{\mathrm{KO}} \mathrm{PK}-15$ cells were treated with vehicle or cholesterol $\left(0.003 \mu \mathrm{g} \mathrm{mL}{ }^{-1}\right)$ for $4 \mathrm{~h}$ followed by PRV $\mathrm{HN} 1201(\mathrm{H}, \mathrm{MOI}=0.1)$ or VSV-GFP $(\mathrm{I}, \mathrm{MOI}=0.01)$ infection for $24 \mathrm{~h}$, and the viral titers were determined by a TCID 50 assay. $*, P<0.05 ; * *, P<0.01 ; * * *$, $P<0.001$; one-way ANOVA. 
9C). Importantly, PRV-infected mice treated with U18666A showed a significantly attenuated pulmonary pathology, including increased necrosis, increased numbers of inflammatory cells, and pulmonary edema induced by PRV HN1201 infection, compared with vehicle-treated mice (Figure 9D). PRV is a neurotropic alphaherpesvirus that, after intranasal infection of mice, propagates to the central nervous system. Using an immunofluorescence assay, we found that U18666A treatment almost completely protected the brain from PRV infection (Figure 9E). We further tested the antiviral efficacy of U18666A against PRV co-expressing luciferase (PRV-Luc) and measured viral lytic growth kinetics in real-time by bioluminescence. Luminescence intensities revealed that U18666A treatment ameliorated virusassociated luciferase activity (Figure 9F).

In parallel, U18666A treatment also protected mice from influenza A virus (H1N1) infection, showing enhanced survival rates (Figure 10A), decreased cytokine production (Figure 10B and C), and lower viral loads (Figure 10C and D). Histopathological examination revealed that U18666A treatment ameliorated virus-associated pulmonary inflammatory infiltration and bronchopneumonia (Figure $10 \mathrm{E})$. Furthermore, we examined whether itraconazole could be used to protect against virus infection in vivo. In line with the inhibitory effects of U18666A, itraconazole protected mice from PRV and H1N1 infection in vivo (Figure S8 in Supporting Information). Together, our findings have demonstrated in vivo that the NPC1 is a possible preventive target that protects against both DNA and RNA virus infections.

\section{DISCUSSION}

Emerging and reemerging viral pathogens pose severe challenges for public health because they evolve continuously, leading to new phenotypic properties that take advantage of changing host and environmental opportunities, making them unable to be eliminated in the foreseeable future. In late 2019, SARS-CoV-2, which causes the disease known as coronavirus disease 2019 (COVID-19), spread rapidly throughout the world, leading to a high death toll and an ongoing pandemic (Lu et al., 2020). The novelty of this newly emerged virus means that no specific antiviral drugs or vaccines have so far proven effective for the treatment of COVID-19 patients. To date, remdesivir that targets viral RNA-dependent RNA polymerases is one of the most promising candidate antivirals. However, the first randomized controlled trial demonstrated that remdesivir did not provide significant benefits over the placebo (Wang et al., 2020b). Moreover, studies showed that the use of chloroquine and hydroxychloroquine in COVID-19 patients is premature and potentially harmful (Ferner and Aronson, 2020). Faced with this situation, the need to search for new broad-spectrum antivirals to control unforeseen epidemics at their onset and improve patients' outcomes is urgent.

Viruses are parasitic and require host cells to carry out their life cycle. Besides proteins and nucleic acids, many viruses subvert cell machinery for lipid synthesis, transport, and storage. Lipids are molecules that provide an energy supply, they are structural components of membranes, and they also participate in cellular signaling and protein modification that influences the propagation of multiple viruses. The characterization of the relationship between viruses and host cell lipids will be fundamental to identifying new targets for antiviral drug development. We developed and performed screening assays using a library of compounds targeting host lipid metabolic factors to identify inhibitors of DNA and RNA virus infection. Among them, U18666A markedly inhibited a wide range of enveloped viruses by specifically targeting NPC1 (Figures 1 and 2). High concentration of U18666A exhibits multiple effects unrelated to its ability as a lysosomal cholesterol efflux blocker (Liscum and Faust, 1989). Whereas, we genetically inhibited NPC1 and found that inhibition of NPC1 dampens viral entry in vitro. Additionally, itraconazole also inhibited PRV and H1N1 infection in vivo (Figure S8 in Supporting Information). These data exclude the side effect of U18666A on virus proliferation.

We compared antiviral activity following U18666A treatment and NPC1 deficiency and demonstrated that NPC1 inhibition offers a protective function against viral infection, suggesting the essential role of NPC1 in the replication of a wide range of enveloped viruses. NPC1, an essential protein involved in cholesterol delivery from the lysosomal lumen to the membrane, is highly conserved and ubiquitously expressed among mammalian cells (Bokelmann et al., 2020). A previous report demonstrated that an Ebola virus surface glycoprotein binds to luminal loop 2 of NPC1, which serves as a passive attachment site for downstream cellular infection (Miller et al., 2012). NPC1 inhibition also impairs the replication of DENV (Poh et al., 2012) and hepatitis E virus (Yin et al., 2016). For HCV, NPC1 inhibition leads to the accumulation of mature viral particles in exosomes (Elgner et al., 2016).

Nevertheless, NPC1 is an unlikely receptor for these viruses, as is the case for the Ebola virus. Using the viral attachment/internalization assay, the cell surface biotinylation assay, and transmission electron microscopy, we provide evidence that NPC1 inhibition does not affect virus-host cell attachment, but rather inhibits viral entry (Figures 3 and 4). When treated with a panel of endocytosis inhibitors, we noted that the treatment of CME inhibitors could significantly reduce PRV and VSV replication, and administration of CME inhibitors in $\mathrm{NPC}^{\mathrm{KO}}$ cells did not show any additional inhibition of viral replication. We, therefore, 
A

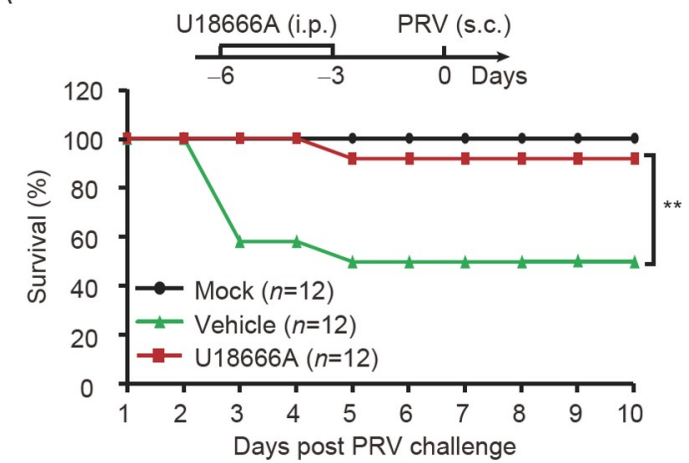

C

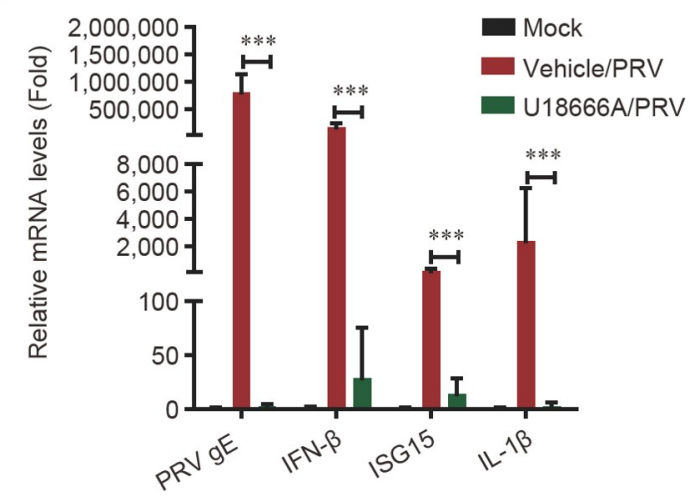

D

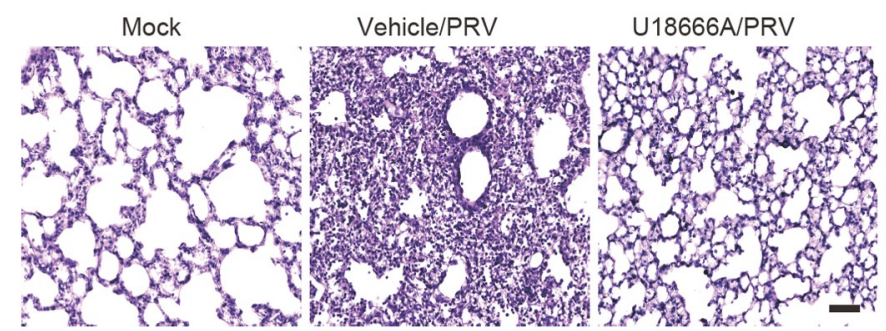

F

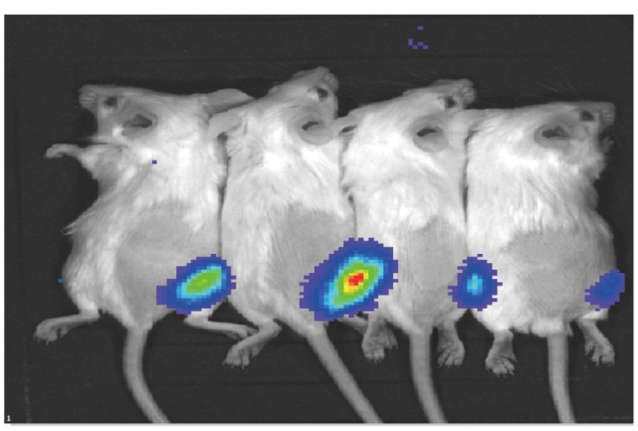

E
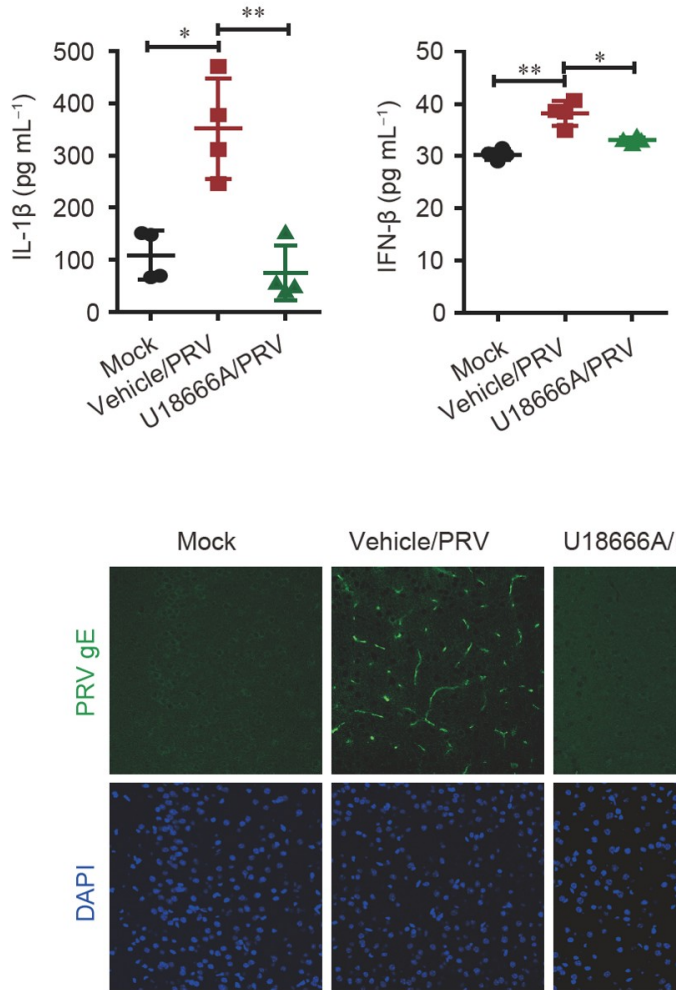

U18666A/PRV
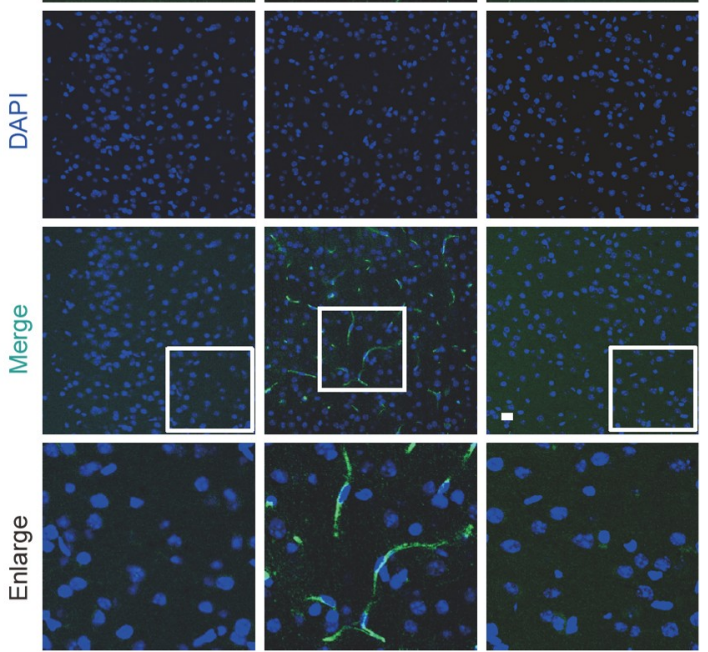

U18666A

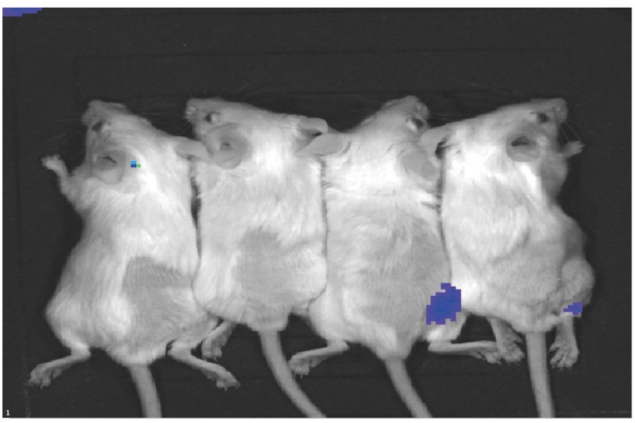

luminescence

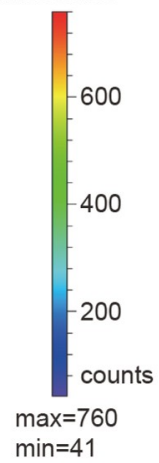

20 h post PRV-GFP-Luc challenge

Figure 9 U18666A inhibits PRV infection in vivo. A, Each group of mice $(n=12)$ intraperitoneally (i.p.) injected with vehicle or U18666A (30 mg kg $\left.{ }^{-1}\right)$ were subcutaneously (s.c.) infected with PRV HN1201 $\left(1 \times 10^{6} \mathrm{TCID}_{50}\right)$ to examine the survival rates. After $10 \mathrm{~d}$, when the animals no longer died, mice were euthanized under ether anesthesia. B, Each group of mice $(n=4)$ intraperitoneally injected with vehicle or U18666A $\left(30 \mathrm{mg}^{-1}\right)$ were intranasally infected with non-lethal doses of PRV HN1201 $\left(3 \times 10^{3}\right.$ TCID $\left._{50}\right)$ for $2 \mathrm{~d}$ to detect serum IL- $1 \beta$ and IFN- $\beta$ concentrations by ELISA. C, The indicated mRNAs in the lungs of mice from (B) were detected by qRT-PCR. D, Lung damage of mice in (B) was assessed by H\&E staining. Scale bar, $50 \mu \mathrm{m}$. E, Each group of mice $(n=5)$ intraperitoneally injected with vehicle or U18666A $\left(30 \mathrm{mg} \mathrm{kg}^{-1}\right)$ were subcutaneously injected with non-lethal doses of PRV HN1201 $\left(1 \times 10^{5}\right.$ TCID $\left.{ }_{50}\right)$ for $7 \mathrm{~d}$ to detect PRV in their brains by immunofluorescence staining of PRV gE. Scale bar, $20 \mu \mathrm{m}$. F, Each group of mice ( $n=4)$ intraperitoneally injected with vehicle or U18666 A $\left(30 \mathrm{mg} \mathrm{kg}^{-1}\right)$ were intramuscularly infected with PRV-Luc $\left(1 \times 10^{4.5} \mathrm{TCID}_{50}\right)$ for $20 \mathrm{~h}$ to measure viral growth in real-time by bioluminescence. *,$P<0.05$; **, $P<0.01$; ***, $P<0.001$; one-way ANOVA. 

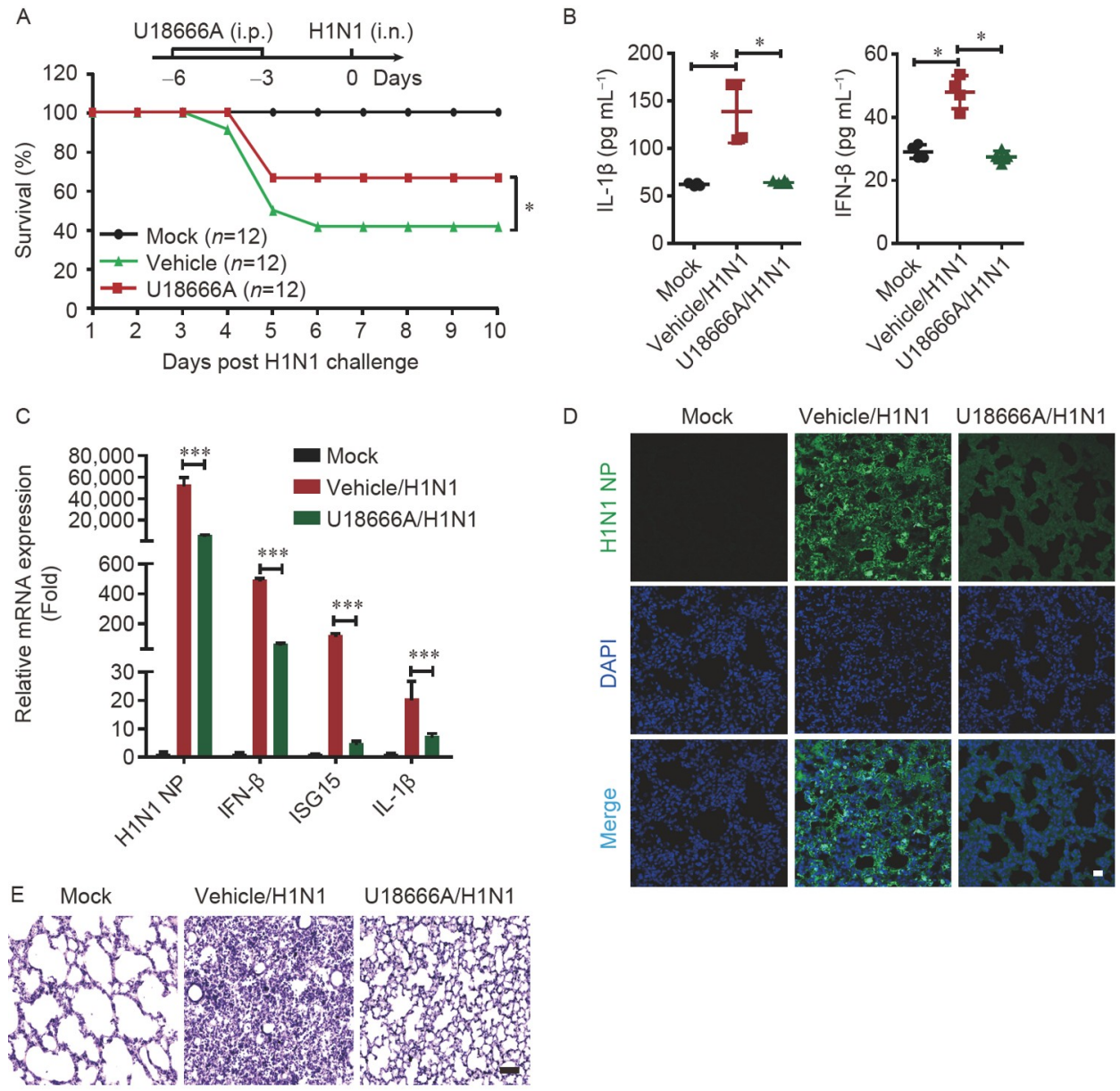

Figure 10 U18666A inhibits H1N1 infection in vivo. A, Each group of mice ( $n=12)$ intraperitoneally (i.p.) injected with vehicle or U18666A (30 mg kg $\left.{ }^{-1}\right)$ were intranasally (i.n.) infected with H1N1-PR8 $\left(\mathrm{LD}_{50}\right)$ to examine the survival rates. B, Each group of mice $(n=4)$ intraperitoneally injected with vehicle or U18666A $\left(30 \mathrm{mg} \mathrm{kg}^{-1}\right)$ were intranasally infected with H1N1-PR8 $\left(\mathrm{LD}_{50}\right)$ for $2 \mathrm{~d}$ to detect serum IL- $1 \beta$ and IFN- $\beta$ concentrations by ELISA. C, The indicated mRNAs in the lungs of mice from (B) were detected by qRT-PCR. D, H1N1 replication in the lungs of mice from (B) was determined by immunofluorescence staining against H1N1 NP. Scale bar, $20 \mu \mathrm{m}$. E, Lung damage of mice in (B) was assessed by H\&E staining. Scale bar, $50 \mu \mathrm{m}$. *, $P<0.05$; ***, $P<0.001$; oneway ANOVA.

propose that NPC1-dependent virus entry relies on CME (Figure 5). However, in the presence of U18666A, the subcellular localization of CME components, and virus recognition in CCPs, remained unperturbed.

These observations raise the question of whether U18666A treatment or NPC1 deficiency impedes viral entry due to NPC1 dysfunction in mediating cholesterol transport. Cholesterol is a critical plasma membrane component that determines membrane fluidity and architecture. For some viruses, cholesterol plays an essential role in the process of virus entry into cells, for example, PRV (Desplanques et al., 2008), foot-and-mouth disease virus (Martín-Acebes et al., 2007), and human rhinovirus type 2 (Snyers et al., 2003), whose entry into cells by CME, requires the presence of PM cholesterol, while depletion of cholesterol by methyl- $\beta$-cyclodextrin $(\mathrm{M} \beta \mathrm{CD})$ significantly inhibits viral entry and infection. However, the mechanism of action of cholesterol in CME-mediated viral entry remains to be addressed. Cholesterol depletion may affect entry due to a change in the biophysical properties of the PM, such as alterations in membrane tension, bending stiffness, or thickness. Previous reports have shown that high membrane tension correlates with endocytosis inhibition (Dai et al., 1997). Reducing PM cholesterol by $\mathrm{M} \beta \mathrm{CD}$ causes an increase in membrane tension (Pontes et al., 2017). We found that U18666A addition induces cholesterol accumulation in lysosomes and decreases PM-cholesterol in different cells (Figure S6A-C in Supporting Information).

Experiments in living cells demonstrate that U18666Amediated inhibition of CME results from defects in CCP dynamics, which acutely interfere with transferrin endocytosis, entry of PRV, VSV, and SARS-CoV-2 pseudoviruses (Figures 6 and 7). To confirm that the stalling of CCP dynamics by the depletion of PM cholesterol under NPC1 dysfunction is the mechanism of viral entry inhibition, we demonstrated that the requirement of $\mathrm{CCP}$ dynamics for viral entry and infectivity could be supplanted by adding exogenous cholesterol (Figures 7 and 8). These data suggest a 
model wherein U18666A or NPC1 deficiency induces depletion of PM cholesterol, which leads to the defect in CCP dynamics. This results in inefficient maturation of CCPs to form CCVs detaching from the PM, impeding transferrin endocytosis and efficient viral entry.

Apart from a possible translational application of the NPC1-CCP dynamic module, this study has elucidated a critical molecular mechanism showing that cholesterol levelmediated viral entry is a valid target for therapeutic intervention. One of the significant barriers in antiviral therapy is potential cytotoxicity. It is well-established that M $\beta C D$ extracts cholesterol from the cell membrane; however, the use of M $B C D$ is limited due to its cytotoxic effects (Kiss et al., 2010). Our study reveals that U18666A exerts no apparent cytotoxicity in vitro or in vivo (Figures S4 and S7 in Supporting Information). Moreover, the effects of U18666A on cholesterol accumulation were fully reversible when the drug was withdrawn (Figure S4C in Supporting Information).

In animal models, the administration of U18666A in vivo reduces PRV and H1N1 infection in mice. According to Tomoyoshi et al., when U18666A was administered to cats experimentally infected with type I feline infectious peritonitis (FIP) virus, the development of FIP might be suppressed compared with the control group (Doki et al., 2020). Combined with our findings, U18666A is considered to be a very promising broad-spectrum antiviral agent. Significantly, U18666A inhibits the spread of neurotropic virus PRV in the brain and alleviates the damage of respiratory virus H1N1 in the lungs (Figures 9 and 10). Compared with the vehicle control, the administration of U18666A was associated with a reduced inflammatory response during the PRV and H1N1 infection periods. COVID-19 pneumonia differs from other respiratory virus infections in the severity of inflammation, and the so-called "cytokine storm" that is elicited, which is the most dangerous and life-threatening event related to COVID-19 (Subbarao and Mahanty, 2020). The potent anti-inflammatory effects of U18666A in mouse models (Figure 9) suggest that it might be beneficial to counter SARS-CoV-2 infection. Our study also provides vital support to the hypothesis that SARS-CoV-2 enters cells primarily via CME. Hence, we predict that the NPC1 inhibitor developed here, or other drugs interfering with host CCP dynamics, may serve as lead compounds for future drug development that block the entry of viruses that utilize CME, including Ebola virus (Bhattacharyya et al., 2010), human immunodeficiency virus (HIV) (Daecke et al., 2005), and HCV (Blanchard et al., 2006).

In summary, our results identify a broader role for cellular cholesterol in regulating CCP dynamics and impacting on viral entry. These findings may provide new broad-spectrum antiviral strategies for treating many enveloped virus infections including suppressing cholesterol biosynthesis or uptake, stimulating cholesterol storage, and preventing cholesterol from being trafficked to the PM by modulating the function of cholesterol transfer proteins.

\section{MATERIALS AND METHODS}

\section{Ethics statement}

Experiments involving animals were approved by the Committee on the Ethics of Animal Care and Use of the National Research Center for Veterinary Medicine. The study was conducted in accordance with the Guide for the Care and Use of Animals in Research of the People's Republic of China.

\section{Mice}

Female 6-8-week-old BALB/c mice were purchased from the Center of Experimental Animal of Zhengzhou University (Zhengzhou, China) and maintained in a specific-pathogenfree animal facility according to the Guide for the Care and Use of Laboratory Animals and the related ethical regulations instilled at Henan Agricultural University.

\section{Cells and viruses}

PK-15, 3D4/21, HeLa, HEK293T, A549, MDCK, and MARC-145 cells were used as previously described (Wang et al., 2020a). CHO-K1 and CT43 cells were gifts from BaoLiang Song (Wuhan University, China). L929 cells were purchased from the Cell Bank of Kunming (KCB92012YJ, China) and cultured in DMEM (Gibco, USA) supplemented with $10 \%$ FBS (Gibco), 100 units per $\mathrm{mL}$ penicillin, and $100 \mu \mathrm{g} \mathrm{mL}^{-1}$ streptomycin sulfate (Sangon Biotech, Shanghai, China). All cells were grown in monolayers at $37^{\circ} \mathrm{C}$ under $5 \% \mathrm{CO}_{2}$.

PRV-GFP, PRRSV BJ-4, VSV-GFP, H1N1-PR8, HSV1-F, and EdU-labeled PRV HN1201 were used as previously described (Wang et al., 2020a). PRV HN1201 was a gift from Ke-Gong Tian (Henan Agricultural University, China) (Xiang et al., 2016). MHV A59 was a gift from Shao-Bo Xiao (Huazhong Agricultural University, China) (Ding et al., 2017). SARS-CoV-2 spike-bearing pseudovirus (LV-SpikenCoV-EGFP) was from PackGene Biotech (Guangzhou, China).

\section{Generation of recombinant PRV-Luc}

PRV strain HN1201 was used as the parental strain of the recombinant virus PRV-Luc. The EGFP expression cassette was under the control of the chicken beta-actin promoter, and the firefly luciferase expression cassette was under the control of the SV40 promoter. The gI and gE genes of PRV HN1201 were knocked out by the CRISPR/Cas9 system. 
Then, the expression cassettes containing the EGFP and luciferase genes were inserted into the DNA deletion sites using the intracellular homologous recombination gene repair system. The recombinant virus was further purified by endpoint dilution.

\section{Chemical reagents}

PF429242, FAS-IN-1, A939572, MK-8245, Plurisin 1, K145, PF-543, Mevastatin, Simvastatin, Ro 48-8071, NB598, AM251, AM630, Otenabant, Nystatin, EIPA, (-)-Blebbistatin, Dynasore, Cholesterol, CPZ, D-Luciferin sodium salt, Posaconazole, and Itraconazole were from MedChemExpress (USA). Filipin III, Zaragozic acid A, YM53601, BIBB 515, and TMP-153 were from Santa Cruz Biotechnology (USA); Cytochalasin D was from Abcam (USA); Phenylarsine oxide and Filipin complex were from Sigma-Aldrich (USA); U18666A was from Cayman Chemical Company (USA); Alexa Fluor 488 conjugated transferrin was from Thermo Fisher Scientific (USA); SARSCoV-2 Spike protein and SARS-CoV-2 Spike S1 antibody were from GenScript (Nanjing, China).

\section{Plasmid constructs and transfection}

Full-length mouse NPC1 cDNA was cloned into the p3 $\times$ FLAG-CMV-14 expression plasmid (Sigma-Aldrich) using the HindIII and KpnI restriction sites. Full-length porcine $A P 2 B 1$ and $A P 2 M 1$ cDNAs were cloned into the mCherry-N1 expression plasmid (Clontech, USA) using the BamHI and KpnI restriction sites. Primers for membrane location signal peptide (Fw: 5'-GATCCATGAAGTCGTGCTTCGCATGCCTAGTCTGCTTCATGGGACGTAAGAAGCGACGACAGCGACGACGACGG-3'; Rv: 5'-GATCCCGTCGTCGTCGCTGTCGTCGCTTCTTACGTCCCATGAAGCAGACTAGGCATGCGAAGCACGACTTCATG-3') were synthesized, annealed, and cloned into the mCherry-N1 plasmid by the Bam HI restriction site to generate cell membrane localization plasmid 21aa-mCherry. All plasmids were transfected with Lipofectamine 3000 (Invitrogen, USA) according to the manufacturer's instructions.

\section{Cell viability assay}

Cell viability was evaluated using a Cell Counting Kit-8 (CCK-8) assay according to the manufacturer's instructions (CCK-8, Beijing Dingguo Changsheng Biotechnology Co. Ltd, China). Briefly, cells were seeded into 96-well plates at $0.8 \times 10^{4}$ per well. The next day, the medium was changed to $\mathrm{DMEM} / 10 \%$ FBS supplemented with U18666A $\left(0-10 \mu \mathrm{g} \mathrm{mL}^{-1}\right)$ and cells were incubated for 24-60 h. At specific time points, CCK-8 $(10 \mu \mathrm{L})$ was then added to each well, and the cells were incubated at $37^{\circ} \mathrm{C}$ for $3 \mathrm{~h}$. The absorbance was detected at $450 \mathrm{~nm}$ with a microplate reader (VARIOSKAN FLASH, Thermo Fisher Scientific).

\section{Flow cytometry assay}

For screening assays, PK-15 cells were pre-treated with the indicated compounds for $4 \mathrm{~h}$, then infected with PRV-GFP $(\mathrm{MOI}=0.01)$ or VSV-GFP $(\mathrm{MOI}=0.00001)$ for $36 \mathrm{~h}$ in the continued presence of compounds. Cells were digested with trypsin-EDTA (Gibco), collected by centrifugation, and suspended in phosphate-buffered saline (PBS). The percentage of GFP-positive cells was measured by flow cytometry on a Beckman CytoFLEX instrument. All data were analyzed with the CytExpert software.

\section{Viral titer assays}

The $50 \%$ tissue culture infective dose $\left(\mathrm{TCID}_{50}\right)$ assay was performed to assess viral titers. On day 0 , cells were seeded in 96 -well plates at a density of $1 \times 10^{4}$ per well. On day 1 , cells were inoculated with serially-diluted viruses $\left(10^{-1}-\right.$ $10^{-12}$ fold) at $37^{\circ} \mathrm{C}$ for $1 \mathrm{~h}$. Excess virus inoculum was removed by washing three times with PBS. Then, $200 \mu \mathrm{L}$ of maintenance medium (DMEM/2\% FBS) was added to each well, and the cells were further cultured for 3-5 d. Cells demonstrating the expected cytopathic effect were observed daily, and the TCID $_{50}$ value was calculated using the ReedMuench method.

The H1N1-PR8 titer was determined by a hemagglutination (HA) assay. The viral samples were serially diluted with PBS in V-bottom 96-well plates and incubated with $0.5 \%$ of chicken red blood cells for $15 \mathrm{~min}$ at $37^{\circ} \mathrm{C}$. The HA endpoint was the highest sample dilution at which agglutination was observed.

\section{Immunoblot analysis}

The cells were lysed with RIPA lysis buffer (Beyotime, Shanghai, China) plus protease and phosphatase inhibitor cocktail (MedChemExpress) for $30 \mathrm{~min}$ on ice. Cell lysates or supernatants were mixed with SDS loading buffer and denatured at $95^{\circ} \mathrm{C}$ for $15 \mathrm{~min}$. Then, the samples were subjected to SDS-PAGE and transferred to the transfer membrane (Millipore, USA). The membrane was blocked with $5 \%$ nonfat milk (Sangon Biotech) at room temperature for $1 \mathrm{~h}$. The membrane was incubated with the primary antibody at $4^{\circ} \mathrm{C}$ overnight and then incubated with horseradish peroxidase-conjugated secondary antibody for $1 \mathrm{~h}$. Proteins were detected using Luminata Crescendo Western HRP Substrate (Millipore) on a GE AI600 imaging system. The following antibodies were used at 1:2,000 dilution:antiNPC1 (WUHAN SANYING, Wuhan, China), anti-actin 
(WUHAN SANYING), anti-AP2B1 (WUHAN SANYING), anti-AP2M1 (Abcam), anti-Flag (WuXi AppTec, Shanghai, China), anti-HA (Abcam), anti-GFP (Abcam) and anti-H1N1 NP (GeneTex, USA). Antiserum against PRV gE was generated by immunization of mice with purified recombinant $\mathrm{gE}$. The following secondary antibodies were used at 1:5,000 dilutions:donkey anti-human HRP (Jackson ImmunoResearch Laboratories, USA) and donkey anti-mouse HRP (Jackson ImmunoResearch Laboratories). Proteins were detected using the BCA Protein Assay Kit (Beijing Dingguo Changsheng Biotechnology Co.Ltd).

\section{Co-IP}

For transient transfection and Co-IP, HEK293T cells $\left(5 \times 10^{6}\right)$ were transfected with the respective plasmids for $36 \mathrm{~h}$. Cells were then harvested and lysed in $1 \mathrm{~mL}$ of lysis buffer (PBS plus $1 \% \mathrm{NP}-40(\mathrm{v} / \mathrm{v}), 5 \mathrm{mmol} \mathrm{L}^{-1}$ EDTA, $5 \mathrm{mmol} \mathrm{L}^{-1}$ EGTA, protease, and phosphatase inhibitor cocktail) and clarified by centrifugation at $16,000 \times g$ for $10 \mathrm{~min}$ at $4^{\circ} \mathrm{C}$. Next, $900 \mu \mathrm{L}$ aliquots of the lysate were incubated with $40 \mu \mathrm{L}$ of a $1: 1$ slurry of sepharose conjugated with either IgG (GE Healthcare, USA) or anti-Flag mouse mAb (Sigma-Aldrich) for $4 \mathrm{~h}$. The beads were washed four times with lysis buffer and were eluted with SDS sample buffer by boiling for $10 \mathrm{~min}$ before SDS-PAGE and immunoblot analysis.

For endogenous Co-IP, HeLa cells $\left(5 \times 10^{6}\right)$ were transfected with the indicated plasmid for $24 \mathrm{~h}$ and infected with PRV HN1201 (MOI=20) at $4^{\circ} \mathrm{C}$ for $2 \mathrm{~h}$. Cells were then incubated at $37^{\circ} \mathrm{C}$ for $0-30 \mathrm{~min}$ and subjected to Co-IP, as described above.

\section{Immunofluorescence and Filipin staining}

Cells grown on coverslips (Thermo Fisher Scientific) were fixed with $4 \%$ paraformaldehyde (PFA) for $30 \mathrm{~min}$, permeabilized in $0.1 \%$ Triton $\mathrm{X}-100$, and then incubated with PBS plus $10 \%$ FBS $(10 \%$ FBS/PBS) with the primary antibody for $1 \mathrm{~h}$ at room temperature. The cells were washed three times with PBS and then labeled with $10 \%$ FBS/PBS plus the fluorescent secondary antibody (Thermo Fisher Scientific) for $1 \mathrm{~h}$. The cells were finally washed in PBS and mounted in ProLong Diamond with DAPI (Invitrogen). Filipin staining was performed as previously described (Chu et al., 2015). Images were captured on a Zeiss LSM 800 confocal microscope and processed using ImageJ software for quantitative image analysis.

\section{Cell surface biotinylation assay}

PK-15 cells were incubated with PRV HN1201 (MOI=10) at $4^{\circ} \mathrm{C}$ for $2 \mathrm{~h}$. Cells were washed twice with ice-cold PBS-CM (PBS plus $0.1 \mathrm{mmol} \mathrm{L}^{-1} \mathrm{CaCl}_{2}, 1 \mathrm{mmol} \mathrm{L}^{-1} \mathrm{MgCl}_{2}$ ) and then incubated with $1 \mathrm{mg} \mathrm{mL}^{-1}$ EZ-Link NHS-biotin (Thermo Fisher Scientific) in PBS-CM at $4^{\circ} \mathrm{C}$ for $30 \mathrm{~min}$. The unreacted biotin was quenched by $10 \mathrm{mmol} \mathrm{L}^{-1}$ glycine in PBS$\mathrm{CM}$ at $4^{\circ} \mathrm{C}$ for $10 \mathrm{~min}$. Cells were washed twice with icecold PBS-CM and then incubated in pre-warmed culture medium plus $10 \mathrm{mmol} \mathrm{L}^{-1}$ glycine at $37^{\circ} \mathrm{C}$ for the indicated times. Cytosolic and membrane fractions were prepared, as previously described (Wang et al., 2015). The lysates of cytosol and membrane were incubated with NeutrAvidinagarose (Thermo Fisher Scientific) and rotated at $4^{\circ} \mathrm{C}$ for $2 \mathrm{~h}$. The agarose beads were washed three times with homogenization buffer (10 mmol L ${ }^{-1}$ HEPES pH 7.4, $10 \mathrm{mmol} \mathrm{L}^{-1}$ $\mathrm{KCl}, 1.5 \mathrm{mmol} \mathrm{L}^{-1} \mathrm{MgCl}_{2}, 5 \mathrm{mmol} \mathrm{L}{ }^{-1}$ EDTA, $5 \mathrm{mmol} \mathrm{L}^{-1}$ EGTA, $250 \mathrm{mmol} \mathrm{L}^{-1}$ sucrose). Biotinylated proteins were eluted with SDS-PAGE sample buffer and analyzed by SDSPAGE, followed by immunoblot analysis.

\section{qRT-PCR}

Total RNA was isolated with TRIzol reagent (TaKaRa, Japan) and subjected to cDNA synthesis with a PrimeScript RT reagent kit (TaKaRa). qRT-PCR was performed in triplicate using SYBR Premix Ex Taq (TaKaRa) according to the manufacturer's instructions, and data were normalized to the level of $\beta$-actin expression in each sample. Melting curve analysis indicated the formation of a single product in all cases. The $2^{-\Delta \Delta C t}$ method was used to calculate relative expression changes. Quantification of the genome copy number of PRV and VSV was performed as previously described (Wang et al., 2020a). Primers used for qRT-PCR were as follows: human NPC1-Fw: 5'-TGGAGGGATTGTGGTGTTGG-3', human NPC1-Rv: 5'ATCGCTCTTCAGTGG CACAA-3'; human $\beta$-actin-Fw: $5^{\prime}-$ GCACAGAGCCTCGCCTT-3', human $\beta$-actin-Rv: 5'CCTTG CACATGCCGGAG-3'; mouse $\beta$-actin-Fw: $5^{\prime}$ CCCCATTGAACATGGCATTG-3', mouse $\beta$-actin -Rv: $5^{\prime}$ ACGACCAGAGGCATACAGG-3'; mouse IFN- $\beta-F w$ : 5'ATGAGTGGTGGTTG CAGG C-3', mouse IFN- $\beta-\mathrm{Rv}$ : $5^{\prime}$ TGACCTTTCAAATGCAGTAGATTCA-3'; mouse IL- $\beta$ Fw: 5'-GCAG AGCACAAGCCTGTCTTCC-3', mouse IL$\beta$-Rv: 5'-ACCTGTCTTGGCCGAGGACTAAG-3'; mouse ISG15-Fw: 5'-TGGTACAGAACTGCAGCG AG-3', mouse ISG15-Rv: 5'-CAGCCAGAA CTGGTCTTCG-3'; PRV gEFw: 5'-GGCATCGCCAACTTCTTCC-3', H1N1 NP-Fw: 5'AACGG CTGGTCTGACTCACATGAT-3', H1N1 NP-Rv: 5'-AGTGAGCACATCCTGGGATCCATT-3'; PRV gE-Rv: 5'-CCTCGTCCACGTCGTCCTC-3'.

\section{Generation of $n p c 1^{-/-}$knockout cell lines via CRISPR/ Cas9}

Small guide RNAs (sgRNAs) targeting porcine $\mathrm{Npcl}$ (sgNPC1: GGAGAGTGTGGAATCGCATA) were synthe- 
sized and cloned into the lentiCRISPR v2 vector (Addgene, USA). Lentiviral production was the same as that indicated in the method of RNA interference. PK-15 cells were infected with lentiviruses and then selected with puromycin $\left(4 \mu \mathrm{g} \mathrm{mL}^{-1}\right)$ for $7 \mathrm{~d}$. Single clonal knockout cells were obtained by serial dilution and verified by Sanger sequencing and immunoblot analysis.

\section{Transmission electron microscopy}

PK-15 cells were treated with U18666A $\left(10 \mu \mathrm{g} \mathrm{mL}^{-1}\right)$ for $4 \mathrm{~h}$ followed by infection with PRV HN1201 (MOI $=100)$ at $4{ }^{\circ} \mathrm{C}$ for $2 \mathrm{~h}$ in the continued presence of U18666A, then the temperature was shifted to $37^{\circ} \mathrm{C}$ for $10 \mathrm{~min}$ to allow for internalization. After three washes with PBS, cells were fixed with $1 \%$ glutaraldehyde for 30 min, postfixed with $1 \%$ osmium tetroxide for $1 \mathrm{~h}$, washed with PBS, dehydrated, and embedded in EPON 812. Ultrathin sections were cut and post-stained with aqueous uranyl acetate and lead citrate. Images were taken on an FEI Tecnai G2 Spirit Transmission Electron Microscope operated at $120 \mathrm{kV}$.

\section{FRAP}

Time series were carried out after HeLa cells were transiently transfected with AP2B1-mCherry for $24 \mathrm{~h}$ and then treated with the indicated compounds for another $8 \mathrm{~h}$. Cells were imaged for $30 \mathrm{~s}$, then bleached for $30 \mathrm{~s}$ at maximum laser intensity in a region of $7 \mu \mathrm{m} \times 7 \mu \mathrm{m}$, and imaged for an additional $5 \mathrm{~min}$. Fluorescence recovery was analyzed by defining CCPs in the FRAP region before bleaching, followed by measuring the fluorescence intensity in the FRAP region over time on a Zeiss LSM 800 confocal microscope.

\section{Live cell imaging}

For time-lapse fluorescence imaging, cells were plated in a $35 \mathrm{~mm}$ glass-bottom dish and transfected with the indicated plasmids $24 \mathrm{~h}$ before imaging. Images were acquired using a Zeiss LSM 800 confocal microscope at $37^{\circ} \mathrm{C}$ with $5 \% \mathrm{CO}_{2}$. Movies were made from time-lapse images using Volocity software.

\section{Dye conjugation to PRV HN1201 particles}

PRV particles were purified by iodixanol density gradient centrifugation as described previously (Zeng et al., 2020). Alexa Fluor 488 (Thermo Fisher Scientific) was solubilized in DMSO at $10 \mathrm{mg} \mathrm{mL}^{-1}$ and incubated at a final concentration of $62.5 \mu \mathrm{g} \mathrm{mL}^{-1}$ with purified PRV HN1201 $\left(1 \mathrm{mg} \mathrm{mL}^{-1}\right)$ in $0.1 \mathrm{~mol} \mathrm{~L}^{-1} \mathrm{NaHCO}_{3}(\mathrm{pH} 8.3)$ for $90 \mathrm{~min}$ at room temperature. Viruses were separated from free dye using a NAP-5 gel filtration column (GE Healthcare), eluted in PBS, and stored at $-80^{\circ} \mathrm{C}$.

\section{In vivo experiments}

Mice $(n=6)$ were intraperitoneally injected with vehicle or U18666 A (0-50 mg kg-1) once every $3 \mathrm{~d}$ for $12 \mathrm{~d}$ to test toxicity. Mice were weighed every day from the first day of injection. Tissues dissected from mice were fixed in $4 \%$ PFA overnight, embedded in paraffin, and sectioned for hematoxylin and eosin (H\&E) staining.

Mice were intraperitoneally injected with vehicle or U18666 A ( $30 \mathrm{mg} \mathrm{kg}^{-1}$ ) once every $3 \mathrm{~d}$ for $6 \mathrm{~d}$ to test antiviral potency. On the next day, mice were intranasally infected with PRV HN1201 $\left(3 \times 10^{3}\right.$ TCID $\left._{50}\right)$, subcutaneously injected with PRV HN1201 $\left(1 \times 10^{6} \mathrm{TCID}_{50}\right)$ for $0-10 \mathrm{~d}$, or intranasally infected with H1N1-PR8 $\left(\mathrm{LD}_{50}\right)$ for $0-10 \mathrm{~d}$.

To determine the expression of PRV $\mathrm{gE}$ in brain sections, we used immunofluorescence. Briefly, brain sections were stained with anti-gE (1:200), then incubated with secondary antibody (anti-mouse IgG antibody labeled with Alexa Fluor 488, 1:200) and labeled with DAPI. All sections were photographed at a magnification of $400 \times$.

\section{ELISA}

Mouse serum was collected to examine the concentration of IFN- $\beta$ (PBL assay science) and IL-1 $\beta$ (R\&D Systems), and the activity of ALT (Solarbio) and AST (Solarbio) by enzyme-linked immunosorbent assay (ELISA) kits according to the manufacturer's instructions.

\section{Bioluminescence imaging}

Mice $(n=4)$ were intraperitoneally injected with vehicle or U18666 A (30 $\mathrm{mg} \mathrm{kg}^{-1}$ ) once every $3 \mathrm{~d}$ for $6 \mathrm{~d}$. On the next day, mice were intramuscularly injected with PRV-Luc $\left(1 \times 10^{4.5} \mathrm{TCID}_{50}\right)$ for $20 \mathrm{~h}$, followed by intraperitoneal injection with $100 \mu \mathrm{L}\left(15 \mathrm{mg} \mathrm{mL}^{-1}\right)$ D-luciferin (MedChemExpress). Six minutes later, mice were anesthetized by $1.5 \%$ isoflurane. In vivo imaging was implemented using a PerkinElmer IVIS Lumina III imaging system, and the results were analyzed with Living Image Software (Version 3.0.4, Xenogen).

\section{Statistical analysis}

All data were obtained from at least three independent experiments for quantitative analyses and are expressed as the means \pm standard errors. All statistical analyses were performed with one-way analysis of variance (ANOVA). Significant differences relative to the corresponding controls were accepted at $*, P<0.05, * *, P<0.01$, and $* * *, P<0.001$. For mouse survival studies, Kaplan-Meier survival curves 
were generated and analyzed for statistical significance.

Compliance and ethics The author(s) declare that they have no conflict of interest. The animal experimental procedure was approved by the Ethics Committtee of Henan Agricultural University.

Acknowledgements We thank Bao-Liang Song (Wuhan University, China) for providing CHO-K1 and CT43 cells; Ke-Gong Tian (Henan Agricultural University, China) for providing PRV HN1201; and Shao-Bo Xiao (Huazhong Agricultural University, China) for providing MHV A59.

\section{References}

Altan-Bonnet, N. (2017). Lipid tales of viral replication and transmission. Trends Cell Biol 27, 201-213.

Barrows, N.J., Campos, R.K., Liao, K.C., Prasanth, K.R., Soto-Acosta, R., Yeh, S.C., Schott-Lerner, G., Pompon, J., Sessions, O.M., Bradrick, S. S., et al. (2018). Biochemistry and molecular biology of flaviviruses. Chem Rev 118, 4448-4482.

Bender, F.C., Whitbeck, J.C., Ponce de Leon, M., Lou, H., Eisenberg, R.J., and Cohen, G.H. (2003). Specific association of glycoprotein B with lipid rafts during herpes simplex virus entry. J Virol 77, 9542-9552.

Bhattacharyya, S., Warfield, K.L., Ruthel, G., Bavari, S., Aman, M.J., and Hope, T.J. (2010). Ebola virus uses clathrin-mediated endocytosis as an entry pathway. Virology 401, 18-28.

Blanchard, E., Belouzard, S., Goueslain, L., Wakita, T., Dubuisson, J., Wychowski, C., and Rouille, Y. (2006). Hepatitis C virus entry depends on clathrin-mediated endocytosis. J Virol 80, 6964-6972.

Bokelmann, M., Edenborough, K., Hetzelt, N., Kreher, P., Lander, A., Nitsche, A., Vogel, U., Feldmann, H., Couacy-Hymann, E., and Kurth, A. (2020). Utility of primary cells to examine NPC1 receptor expression in Mops condylurus, a potential Ebola virus reservoir. PLoS Negl Trop Dis 14, e0007952.

Bourke, E., Cassetti, A., Villa, A., Fadlon, E., Colotta, F., and Mantovani, A. (2003). IL-1 $\beta$ scavenging by the type II IL-1 decoy receptor in human neutrophils. J Immunol 170, 5999-6005.

Carneiro, F.A., Lapido-Loureiro, P.A., Cordo, S.M., Stauffer, F., Weissmüller, G., Bianconi, M.L., Juliano, M.A., Juliano, L., Bisch, P. M., Da Poian, A.T., et al. (2006). Probing the interaction between vesicular stomatitis virus and phosphatidylserine. Eur Biophys J 35, $145-154$

Cenedella, R.J., Sarkar, C.P., and Towns, L. (1982). Studies on the mechanism of the epileptiform activity induced by U18666A. II. Concentration, half-life and distribution of radiolabeled U18666A in the brain. Epilepsia 23, 257-268.

Chu, B.B., Liao, Y.C., Qi, W., Xie, C., Du, X., Wang, J., Yang, H., Miao, H. H., Li, B.L., and Song, B.L. (2015). Cholesterol transport through lysosome-peroxisome membrane contacts. Cell 161, 291-306.

Coronaviridae Study Group of the International Committee on Taxonomy of Viruses. (2020). The species Severe acute respiratory syndromerelated coronavirus: classifying 2019-nCoV and naming it SARS-CoV2. Nat Microbiol 5, 536-544.

Cruz, J.C., Sugii, S., Yu, C., and Chang, T.Y. (2000). Role of Niemann-Pick type $\mathrm{C} 1$ protein in intracellular trafficking of low density lipoproteinderived cholesterol. J Biol Chem 275, 4013-4021.

Daecke, J., Fackler, O.T., Dittmar, M.T., and Krausslich, H.G. (2005). Involvement of clathrin-mediated endocytosis in human immunodeficiency virus type 1 entry. J Virol 79, 1581-1594.

Dai, J., Ting-Beall, H.P., and Sheetz, M.P. (1997). The secretion-coupled endocytosis correlates with membrane tension changes in RBL $2 \mathrm{H} 3$ cells. J Gen Physiol 110, 1-10.

Desplanques, A.S., Nauwynck, H.J., Vercauteren, D., Geens, T., and Favoreel, H.W. (2008). Plasma membrane cholesterol is required for efficient pseudorabies virus entry. Virology 376, 339-345.

Ding, Z., Fang, L., Yuan, S., Zhao, L., Wang, X., Long, S., Wang, M.,
Wang, D., Foda, M.F., and Xiao, S. (2017). The nucleocapsid proteins of mouse hepatitis virus and severe acute respiratory syndrome coronavirus share the same IFN- $\beta$ antagonizing mechanism: attenuation of PACT-mediated RIG-I/MDA5 activation. Oncotarget 8, 49655-49670.

Doki, T., Tarusawa, T., Hohdatsu, T., and Takano, T. (2020). In vivo antiviral effects of U18666A against type I feline infectious peritonitis virus. Pathogens 9, 67.

Edeling, M.A., Smith, C., and Owen, D. (2006). Life of a clathrin coat: insights from clathrin and AP structures. Nat Rev Mol Cell Biol 7, 3244.

Ehrlich, M., Boll, W., Van Oijen, A., Hariharan, R., Chandran, K., Nibert, M.L., and Kirchhausen, T. (2004). Endocytosis by random initiation and stabilization of clathrin-coated pits. Cell 118, 591-605.

Elgner, F., Ren, H., Medvedev, R., Ploen, D., Himmelsbach, K., Boller, K., and Hildt, E. (2016). The intracellular cholesterol transport inhibitor U18666A inhibits the exosome-dependent release of mature hepatitis C virus. J Virol 90, 11181-11196.

Ferner, R.E., and Aronson, J.K. (2020). Chloroquine and hydroxychloroquine in COVID-19. BMJ 369, m1432.

Grove, J., and Marsh, M. (2011). The cell biology of receptor-mediated virus entry. J Cell Biol 195, 1071-1082.

Heaton, N.S., and Randall, G. (2011). Multifaceted roles for lipids in viral infection. Trends Microbiol 19, 368-375.

Hoffmann, M., Kleine-Weber, H., Schroeder, S., Krüger, N., Herrler, T., Erichsen, S., Schiergens, T.S., Herrler, G., Wu, N.H., Nitsche, A., et al. (2020). SARS-CoV-2 cell entry depends on ACE2 and TMPRSS2 and is blocked by a clinically proven protease inhibitor. Cell 181, 271-280. e8.

Jiang, J., Kolpak, A.L., and Bao, Z.Z. (2010). Myosin IIB isoform plays an essential role in the formation of two distinct types of macropinosomes. Cytoskeleton 67, 32-42.

Kiss, T., Fenyvesi, F., Bácskay, I., Váradi, J., Fenyvesi, E., Iványi, R., Szente, L., Tósaki, A., and Vecsernyés, M. (2010). Evaluation of the cytotoxicity of $\beta$-cyclodextrin derivatives: Evidence for the role of cholesterol extraction. Eur J Pharm Sci 40, 376-380.

Li, M., Yang, C., Tong, S., Weidmann, A., and Compans, R.W. (2002). Palmitoylation of the murine leukemia virus envelope protein is critical for lipid raft association and surface expression. J Virol 76, 1184511852 .

Li, Z., Guo, D., Qin, Y., and Chen, M. (2019). PI4KB on inclusion bodies formed by ER membrane remodeling facilitates replication of human parainfluenza virus type 3. Cell Rep 29, 2229-2242.e4.

Lingwood, D., and Simons, K. (2010). Lipid rafts as a membraneorganizing principle. Science $327,46-50$.

Liscum, L., and Faust, J.R. (1989). The intracellular transport of low density lipoprotein-derived cholesterol is inhibited in Chinese hamster ovary cells cultured with 3- $\beta$-[2-(diethylamino)ethoxy]androst-5-en-17one. J Biol Chem 264, 11796-11806.

Lorizate, M., and Kräusslich, H.G. (2011). Role of lipids in virus replication. Cold Spring Harbor Perspect Biol 3, a004820.

Lozano, R., Naghavi, M., Foreman, K., Lim, S., Shibuya, K., Aboyans, V., Abraham, J., Adair, T., Aggarwal, R., Ahn, S.Y., et al. (2012). Global and regional mortality from 235 causes of death for 20 age groups in 1990 and 2010: a systematic analysis for the Global Burden of Disease Study 2010. Lancet 380, 2095-2128.

Lu, F., Liang, Q., Abi-Mosleh, L., Das, A., De Brabander, J.K., Goldstein, J.L., and Brown, M.S. (2015). Identification of NPC1 as the target of U18666A, an inhibitor of lysosomal cholesterol export and Ebola infection. eLife 4, e12177.

Lu, R., Zhao, X., Li, J., Niu, P., Yang, B., Wu, H., Wang, W., Song, H., Huang, B., Zhu, N., et al. (2020). Genomic characterisation and epidemiology of 2019 novel coronavirus: implications for virus origins and receptor binding. Lancet 395, 565-574.

Martín-Acebes, M.A., González-Magaldi, M., Sandvig, K., Sobrino, F., and Armas-Portela, R. (2007). Productive entry of type C foot-and-mouth disease virus into susceptible cultured cells requires clathrin and is 
dependent on the presence of plasma membrane cholesterol. Virology 369, 105-118.

Menendez-Arias, L., Alvarez, M., and Pacheco, B. (2014). Nucleoside/ nucleotide analog inhibitors of hepatitis B virus polymerase: mechanism of action and resistance. Curr Opin Virol 8, 1-9.

Mercer, J., and Helenius, A. (2009). Virus entry by macropinocytosis. Nat Cell Biol 11, 510-520.

Mettlen, M., Chen, P.H., Srinivasan, S., Danuser, G., and Schmid, S.L. (2018). Regulation of clathrin-mediated endocytosis. Annu Rev Biochem 87, 871-896.

Miller, E.H., Obernosterer, G., Raaben, M., Herbert, A.S., Deffieu, M.S., Krishnan, A., Ndungo, E., Sandesara, R.G., Carette, J.E., Kuehne, A.I., et al. (2012). Ebola virus entry requires the host-programmed recognition of an intracellular receptor. EMBO J 31, 1947-1960.

Miller, S., and Krijnse-Locker, J. (2008). Modification of intracellular membrane structures for virus replication. Nat Rev Microbiol 6, 363374.

Monnerie, H., Romer, M., Jensen, B.K., Millar, J.S., Jordan-Sciutto, K.L., Kim, S.F., and Grinspan, J.B. (2017). Reduced sterol regulatory element-binding protein (SREBP) processing through site-1 protease (S1P) inhibition alters oligodendrocyte differentiation in vitro. J Neurochem 140, 53-67.

Moriishi, K., and Matsuura, Y. (2012). Exploitation of lipid components by viral and host proteins for hepatitis $\mathrm{C}$ virus infection. Front Microbio 3, 54.

Nio, Y., Hasegawa, H., Okamura, H., Miyayama, Y., Akahori, Y., and Hijikata, M. (2016). Liver-specific mono-unsaturated fatty acid synthase-1 inhibitor for anti-hepatitis C treatment. Antiviral Res 132, 262-267.

Nixdorf, R., Schmidt, J., Karger, A., and Mettenleiter, T.C. (1999). Infection of Chinese hamster ovary cells by pseudorabies virus. J Virol 73, 8019-8026.

Poh, M.K., Shui, G., Xie, X., Shi, P.Y., Wenk, M.R., and Gu, F. (2012). U18666A, an intra-cellular cholesterol transport inhibitor, inhibits dengue virus entry and replication. Antiviral Res 93, 191-198.

Pontes, B., Monzo, P., and Gauthier, N.C. (2017). Membrane tension: A challenging but universal physical parameter in cell biology. Semin Cell Dev Biol 71, 30-41.

Shin, S.Y., Lee, K.S., Choi, Y.K., Lim, H.J., Lee, H.G., Lim, Y., and Lee, Y. H. (2013). The antipsychotic agent chlorpromazine induces autophagic cell death by inhibiting the Akt/mTOR pathway in human U-87MG glioma cells. Carcinogenesis 34, 2080-2089.

Smith, D., Magri, A., Bonsall, D., Ip, C.L.C., Trebes, A., Brown, A., Piazza, P., Bowden, R., Nguyen, D., Ansari, M.A., et al. (2019). Resistance analysis of genotype 3 hepatitis $\mathrm{C}$ virus indicates subtypes inherently resistant to nonstructural protein $5 \mathrm{~A}$ inhibitors. Hepatology 69, 1861-1872.

Snyers, L., Zwickl, H., and Blaas, D. (2003). Human rhinovirus type 2 is internalized by clathrin-mediated endocytosis. J Virol 77, 5360-5369.

Stapleford, K.A., and Miller, D.J. (2010). Role of cellular lipids in positivesense RNA virus replication complex assembly and function. Viruses 2,
$1055-1068$.

Subbarao, K., and Mahanty, S. (2020). Respiratory virus infections: understanding COVID-19. Immunity 52, 905-909.

Subtil, A., Gaidarov, I., Kobylarz, K., Lampson, M.A., Keen, J.H., and McGraw, T.E. (1999). Acute cholesterol depletion inhibits clathrincoated pit budding. Proc Natl Acad Sci USA 96, 6775-6780.

Targett-Adams, P., Boulant, S., Douglas, M.W., and McLauchlan, J. (2010). Lipid metabolism and HCV infection. Viruses 2, 1195-1217.

Trinh, M.N., Lu, F., Li, X., Das, A., Liang, Q., De Brabander, J.K., Brown, M.S., and Goldstein, J.L. (2017). Triazoles inhibit cholesterol export from lysosomes by binding to NPC1. Proc Natl Acad Sci USA 114, 8994.

Tsai, B., and Qian, M. (2010). Cellular entry of polyomaviruses. In: Johnson, J., ed. Cell Entry by Non-Enveloped Viruses. Current Topics in Microbiology and Immunology. Berlin: Springer. 177-194.

Tscherne, D.M., Jones, C.T., Evans, M.J., Lindenbach, B.D., McKeating, J. A., and Rice, C.M. (2006). Time- and temperature-dependent activation of hepatitis C virus for low-pH-triggered entry. J Virol 80, 1734-1741.

Wang, H., Yang, P., Liu, K., Guo, F., Zhang, Y., Zhang, G., and Jiang, C. (2008). SARS coronavirus entry into host cells through a novel clathrinand caveolae-independent endocytic pathway. Cell Res 18, 290-301.

Wang, J., Chu, B., Du, L., Han, Y., Zhang, X., Fan, S., Wang, Y., and Yang, G. (2015). Molecular cloning and functional characterization of porcine cyclic GMP-AMP synthase. Mol Immunol 65, 436-445.

Wang, J., Li, G.L., Ming, S.L., Wang, C.F., Shi, L.J., Su, B.Q., Wu, H.T., Zeng, L., Han, Y.Q., Liu, Z.H., et al. (2020a). BRD4 inhibition exerts anti-viral activity through DNA damage-dependent innate immune responses. PLoS Pathog 16, e1008429.

Wang, Y., Zhang, D., Du, G., Du, R., Zhao, J., Jin, Y., Fu, S., Gao, L., Cheng, Z., Lu, Q., et al. (2020b). Remdesivir in adults with severe COVID-19: a randomised, double-blind, placebo-controlled, multicentre trial. Lancet 395, 1569-1578.

Wisskirchen, K., Lucifora, J., Michler, T., and Protzer, U. (2014). New pharmacological strategies to fight enveloped viruses. Trends Pharmacol Sci 35, 470-478.

Xiang, S., Zhou, Z., Hu, X., Li, Y., Zhang, C., Wang, J., Li, X., Tan, F., and Tian, K. (2016). Complete genome sequence of a variant pseudorabies virus strain isolated in central China. Genome Announc 4.

Yin, X., Ambardekar, C., Lu, Y., and Feng, Z. (2016). Distinct entry mechanisms for nonenveloped and quasi-enveloped hepatitis $\mathrm{E}$ viruses. J Virol 90, 4232-4242.

Zeng, L., Wang, M.D., Ming, S.L., Li, G.L., Yu, P.W., Qi, Y.L., Jiang, D. W., Yang, G.Y., Wang, J., and Chu, B.B. (2020). An effective inactivant based on singlet oxygen-mediated lipid oxidation implicates a new paradigm for broad-spectrum antivirals. Redox Biol 36, 101601.

Zhang, N., Zhao, H., and Zhang, L. (2019). Fatty acid synthase promotes the palmitoylation of chikungunya virus nsP1. J Virol 93.

Zhou, P., Yang, X.L., Wang, X.G., Hu, B., Zhang, L., Zhang, W., Si, H.R., Zhu, Y., Li, B., Huang, C.L., et al. (2020). A pneumonia outbreak associated with a new coronavirus of probable bat origin. Nature 579, 270-273.

\section{SUPPORTING INFORMATION}

The supporting information is available online at https://doi.org/10.1007/s11427-021-1929-y. The supporting materials are published as submitted, without typesetting or editing. The responsibility for scientific accuracy and content remains entirely with the authors. 